\title{
Hakkâri İlinde Gıda Olarak Tüketilen Yabani Bitki ve Yabancı Ot Türlerinin Güncel Durumu
}

\author{
Mesut Sirrı $^{1 *}$, Gülten Sirrı ${ }^{2}$ \\ ${ }^{1}$ Siirt Üniversitesi, Eruh Meslek Yüksekokulu, Bitkisel ve Hayvansal Üretim Bölümü, Siirt, Türkiye (ORCID: 0000-0001-9793-9599) \\ 2 Siirt İl Tarım ve Orman Müdürlüğ̈̈, Gıda ve Yem Şubesi, Siirt, Türkiye (ORCID: 0000-0003-1632-0992)
}

(Illk Geliş Tarihi 4 Mart 2020 ve Kabul Tarihi 13 Haziran 2020)

(DOI: $10.31590 /$ ejosat.697536)

ATIF/REFERENCE: Sırrı, M. \& Sırrı, G. (2020). Hakkâri İlinde Gıda Olarak Tüketilen Yabani Bitki ve Yabancı Ot Türlerinin Güncel Durumu. Avrupa Bilim ve Teknoloji Dergisi, (19), 393-409.

\section{Öz}

Bu çalı̧̧mada Hakkâri ili ve ilçelerinde yöre halkı tarafindan doğal alanlar ve tarımsal ekosistemlerden toplanarak gıda ve/veya tıbbi amaçlarla kullanılan bitkiler ele alınmıştır. Bölgede aşırı toplama sonucu olarak bazı bitkilere artık rastlanmadığı ve neredeyse nesillerinin yok olmaya yüz tuttuğu kamuoyuna yansıyan bu bitkilerin güncel durumunun ortaya konulması hedeflenmiştir. Araştırma kapsamında, 2018 yılı ilkbahar döneminde bitkileri doğada toplayan kişiler ile mülakatlar yapılmış, yerel pazarlarda halktan insanlarla görüşülmüş ve arazi sürveyleri gerçekleştirilmiş̧ir. Ayrıca daha önce bölgede yapılan etnobotanik çalışmalar da dikkate alınarak konuya ilişkin değerlendirmeler yapılmıştır. Yapılan araştırmalar sonucunda bölgede en fazla toplanıp tüketilen Köse otu/Siyabo (Diplotaenia cachrydifolia Boiss.), Yayla muzu/Rrevas (Rheum ribes L.), Kenger/Kengir (Gundelia tournefortii L. var. tournefortii), Tarak otu/Mendi (Chaerophyllum macrospermum (Willd. ex Sprengel), Ters lale/Guldexin (Fritillaria imperialis L.), Çayır salebi/Şepizek (Orchis palustris jacq) ve Yabani mantar/Kivark (Pleurotus eryngii var. ferulae (Lanzi) Sacc.) gibi bitki türlerinin doğada rastlanma sıklıklarının ve yoğunluklarının önemli ölçüde azaldı̆̆ı saptanmıştır. Bunun bir sonucu olarak yörede bitki toplayan ve ticari olarak bunlardan gelir elde eden kişilerin toplama işi için çok daha fazla mesafe kat ettikleri ve daha fazla zaman harcadıkları bu nedenle de bu bitkilerin piyasa fiyatlarının sürekli arttığı saptanmıştır. Bölgede doğal olarak yetişen ve ekonomik değeri son derece yüksek olan bu bitkilerin korunması ve sürdürülebilir bir şekilde toplanabilmeleri için yöre halkına yönelik bilgilendirme ve bilinçlendirme çalışmalarının yapılması gerektiği sonucuna varılmıştır. Bu durum bölgedeki biyolojik çeşitliliğin korunmasına da büyük katkılar sağlayacaktır. Ayrıca en azından bazı türlerin kültüre alınmasının doğal flora üstündeki baskıyı azaltabileceği kanaatine varılmıştır.

Anahtar Kelimeler: Yabani bitki, Yabancı ot, Etnobotanik, Nesli tehlike altında olan türler, Hakkâri

\section{Current Status of Wild Plant and Weed Species Consumed as Food in Hakkâri Province}

\begin{abstract}
In this study, plants used for food and/or medicinal purposes by collecting from natural areas and agricultural ecosystems by local people in Hakkâri province and its districts are discussed. It is aimed to reveal the current status of the plant species, which are reflected in the public, that are not found and/or almost extinct as a result of the excessive collection in the region. Within the scope of the research, interviews were made with the people collectting the plants from nature and with people selling the plants in the local market and surveys were carried out in the natural and agroecosystems in the spring of 2018. In addition, previous ethnobotanical studies have been conducted in the region were also evaluated. As a result of the study, it has been determined that, significant decreases in the frequency and intensity of the most collected and consumed plant species in the region such as Diplotaenia cachrydifolia Boiss., Rheum ribes L., Gundelia tournefortii L. var. Tournefortii, Chaerophyllum macrospermum Willd. ex Sprengel, Fritillaria imperialis L., Orchis palustris jacq, and Pleurotus eryngii var. ferulae (Lanzi) Sacc were observed. It has also been determined that people collecting the plant for commercial purposes search longer distances and spend more time for collection. Therefore, it has been determined that the market prices of these plants are constantly increasing in the region. It has been concluded that information and awareness-raising activities should be carried out for the local people in order to sustainably benefit from these plants and to protect them. This will also contribute to the conservation of biodiversity in the region. It has also been concluded that cultivating at least some species can reduce the pressure on natural flora.
\end{abstract}

Keywords: Wild plant, Weeds, Ethnobotany, Endangered species, Hakkâri.

\footnotetext{
* Sorumlu Yazar: Siirt Üniversitesi, Eruh Meslek Yüksekokulu, Bitkisel ve Hayvansal Üretim Bölümü, Siirt, Türkiye (ORCID: 0000-0001-97939599), $\underline{\text { m.sirri@siirt .edu.tr }}$
} 
Avrupa Bilim ve Teknoloji Dergisi

\section{Giriş}

Biyolojik çeşitlilik bir bölgedeki canlı organizmalar ve yaşam alanlarındaki çeşitliliği ve değişkenliği ifade eden bir olgudur. Dolayısıyla biyolojik çeşitlilik, genetik çeşitliliği, tür çeşitliliği ve ekosistem çeşitliliği olarak dünyada canlıların var oluşundan bu yana ortaya çıkan tarihsel bir birikimdir. Bu oluşum ile ortaya çıkan biyolojik miras bölgesel ölçek ile sınırlı kalmayıp küresel anlamda tüm insanlığın ortak zenginliği ve gelecek nesiller için en değerli mirastır. Ancak insan faaliyetleri nedeniyle doğal yaşam alanları ve biyolojik çeşitlilik giderek daha büyük tehditlerle karşı karşıya kalmaktadır. Özellikle günümüzde kırsal nüfusun köyden kente göç etmesinin artması sonucu oluşan kentsel yapılanma, baraj ve yol çalışmaları, doğal kaynakların aşırı ve bilinçsiz kullanımı, yeraltı kaynakların arama-tarama faaliyetleri, istilacı türlerin etkisi vb hususlar doğal kaynaklar üzerindeki baskının artmasına neden olmaktadır. Bunun sonucunda da biyolojik çeşitlilik için önem taşıyan doğal alanlar gittikçe azalmakta, farklı canlı gruplarının yaşam alanları giderek daraltmakta ve nihayetinde pek çok canlı türünün nesli tükenme noktasına gelmektedir. (Kençe, 1991; Çakmak, 2008; Önen, 2010; Karaer ve ark., 2015; Önen ve ark., 2017).

Dünyada yaklaşık olarak 422.000 çiçekli bitki türünün bulunduğu tahmin edilmektedir (Bramwell, 2002). Bu türlerden yaklaşık 31.000'inin farklı alanlarda (g1da, ilaç, gen, süs bitkisi ve hayvan yemi vb) kullanılırken dünyadaki mevcut bitki türlerinin \%21'nin ise neslinin yok olma tehlikesiyle karşı karşıya olduğu belirtilmektedir (Anonim, 2019). Dolayısıyla kaba bir hesaplamayla dünya genelinde bütün bitkilerin sadece \%8'inden az bir kısmından yararlanılırken her beş bitkiden biri (önemi anlaşılmadan) yok olma tehlikesi altında bulunmakta veya yok olmaktadır.

Ülkemiz bulunduğu coğrafi konum nedeniyle bir geçiş kuşağında yer alması, farklı iklim özellikleri ve zengin doğal su kaynakları bakımından oldukça önemli bir habitat alanıdır. Bu nedenle flora ve faunasında zengin bir tür çeşitliliği bulunmaktadır. Bu çeşitliliğin bir sonucu olarak Türkiye sahip olduğu zengin flora sayesinde birçok bitkinin gen merkezi konumunda olup 12.000'den fazla bitki türüne eve sahipliği yapmaktadır. Türkiye florasında bulunan 3,700’ün üzerinde endemik bitki türü olduğu dikkate alındığında ülkemizdeki biyolojik çeşitliliğin düzeyi daha kolay anlaşılacaktır (Önen, 2010). Bu bitki türlerinden yaklaşık 1.000 kadarının (toplam bitki sayısının \%8 kadarı) gıda, tıbbi amaçlar ve diğer şekillerde kullanıldığı ifade edilmektedir (Davis, 1965-1988; Baytop,1999; Turan, 2007; Karagöz ve ark, 2010; Güler, 2012; Güner ve ark., 2012; Aslan, 2014). Ayrıca tarihsel süreç içerisinde ülkemiz farklı kültürlerdeki birçok medeniyetin hüküm sürdüğü ve önemli ticaret yollarının bulunduğu bir coğrafya olduğu görülmektedir. Özellikle de Mezopotamya coğrafyası, medeniyetlerin beşiği olarak bilinmektedir. Bu coğrafyanın önemli bir parçasını oluşturan Hakkâri bölgesi de coğrafi konum olarak Türkiye, İran ve Irak üçgenini kapsayarak farklı kültürlerdeki medeniyetlerin etkileşimde bulunduğu önemli bir bölgedir. Ayrıca bölgenin kendine özgü iklim ve topografik yapısı bölgeye zengin bir biyolojik çeşitlilik kazandırmıştır. Bölgenin bu eşsiz biyolojik çeşitliliği sayesinde insan-doğa/bitki etkileşimi sağlayarak doğal floradaki bitkilerden gıda, tıp ve endüstriyel amaçlar vb farklı alanlarda yararlanılmasını sağlamıştır.

Son yıllarda küresel ısınmadan kaynaklı iklim değişikliğinin yanında insanların tabiatı dikkate almadan yaptıkları tahribatlar sonucunda bölgenin mevcut biyoçeşitliliği önemli ölçüde etkilenmiştir. Bölgede yabani ve yabancı otlar sadece mutfak kültürünün bir parçası olmayıp baharın müjdeleyicisi olan bu bitkilerin toplanması, pazarlanması, pişirilmesi vb bütün aşamalarıyla yöresel kültürün önemli bir parçası konumundadır. Dolayısıyla bu bitkiler yöre halkı için mutluluk ve sağlık kaynağı olarak görülmekte ve bu anlamda büyük önem taşımaktadır. Bu nedenle de bu bitkilerin mevcut durumları, özellikle yok olma tehlikesi altında olan bitki türlerinin saptanması ve bunların alanlarının koruma altına alınması vb çalışmalar sadece biyoçeşitliliğe değil kültürel mirasın korunmasına da önemli katkı sağlayacaktır. Bu düşünceden yola çıkılarak çalışmayla; Hakkâri yöresinde doğadan toplanan önemli bazı bitki türlerinin mevcut durumunun ortaya konulması, bölgede geleneksel olarak tüketilen önemli bitki türlerinin ve tüketim şekillerinin tanıtılması ve bu kültürün korunması için alınması gereken önlemler tartışılmıştır.

\section{Materyal ve Metot}

Bu çalışma Hakkâri ve ilçelerinde kültürü yapılmayan, doğal florada bulunan yabancı ot ve yabani bitkilerin gıda ve tıbbi amaçla kullanımları ve bunlarda nesli risk altında olan türlerinin belirlenmesi amacıyla; pazarlarda gözlemler ve arazide sürvey çalışmaları yapılmış, yöre halkının bilgi, deneyim ve gözlemlerine başvurulmuş ve bölgede daha önce yapılan etnobotanik çalışmalardan yararlanılmıştır.

Çalışma kapsamında verilerin toplanması için özellikle kırsal kesimlerde yaşayan halkın doğadan topladıkları bitkileri pazarladıkları bölgedeki semt pazarlarına ve aktarlara gidilmişir. Pazarlarda toplayıcılardan bitkilerin toplandığı alanlar ve yıllar içerisinde toplama alanlarındaki değişimin boyutuna ilişkin bilgiler ile bitkilerin tüketim şekline ilişkin bilgiler toplanırken tüketicilerden (farklı yaş ve meslek gruplarındaki bayan ve erkek şahısların bilgilerine başvurularak) bitkilerin kullanım şekline ilişkin veriler derlenmiştir. Araştırma kapsamında yapılan görüşmelerde en çok bilgi aldığımız kişi ve kuruluşlardan bazıları; Cemal DARA (70-Çiftçi), Ayşe ALTEKİN (75-Ev hanımı), İbrahim BUDAK (64-Çiftçi), Güllü SAFALI (80-Ev hanımı), Nizam SIRRI (70-Çiftçi), Ğoği ÇALIŞKAN (71-Sağlatıcı), Kerem KARASAÇ (75-Çiftçi), Namık SIRRI (42- Bitki toplayıcısı), Geci Dara (80-Kırıkçı) Hetem ÇOÇGA (63-Peynirci), Halit KAVAL (Emekli memur), Mustafa KAPLAN (40-Aktarcı), Süleyman DAYAN (53-Çiçekçi), Ayhan AYKUT (40-Aktarc1), Necip ÇAPRAZ (53-Gazeteci), Ömer TAŞ (35-Tarım danışmanı), Barış DİRİ (Ziraat mühendisi), Ömer OĞUZ (32-Muhabir/Fotoğrafçı) yanı sıra İl/İlçe Tarım ve Orman Müdürlükleri ve Ziraat Odaları şeklinde sıralanabilir. Yukarıda bir kısmı belirtilen kişi ve kuruluşlardan derlenen bilgilerle yörede kullanılan bitkilerin genel durumuna ilişkin bilgiler toplanmıştır. Daha sonra başta C. DARA, İ. BUDAK, N. SIRRI, Ğ. ÇALIŞKAN, K. KARASAÇ, N. SIRRI başta olmak üzere yukarıda adı geçen bazı kişilerle beraber arazide sürvey çalışmaları yapılmış ve daha önce isimleri belirlenen (pazarlarda, yüz yüze görüşmelerde vb) bitkiler 
resimlenmiştir. Bölgede bitkilerin tüketim şeklinin belirlenmesi amacıyla yapılan mülakatlarda sürvey çalışmaları sırasında alınan bitki örnekleri ve bitkilere ait görseller yukarıda ismi geçenlere gösterilerek elde edilen bilgiler teyit edilmiş ve bitki envanteri çıkarılmıştır. Belirlenen bitkilerin yöresel isimleri, kullanılan kısımları, kullanım amacı ve şekli literatür bilgileriyle zenginleştirilerek Çizelge 2'de verilmiştir (Baytop, 1999; Özer ve ark., 2002; Özer ve ark., 2004; Kaval, 2011; Polat ve ark., 2012; Uce ve Tunçtürk, 2014; Gül ve Dinler, 2016; Oğuz, 2016).

\section{Araştırma Sonuçları ve Tartışma}

\subsection{Bölgede Doğadan Toplanan Bitki Türleri}

Bölgenin sahip olduğu zengin bitki çeşitliliği yöre halkına doğal ortamlarda yetişen çok sayıda bitkiden farklı amaçlarla yararlanma imkânı sağlamıştır. Yöre halkı da bu bitkileri çok farklı amaçlarla kullanma yoluna gitmiş ve bölgede etnobotanik açıdan kendine has bir kültürel birikim meydana gelmiştir. Yöre halkı bitki toplamayı bir işten ziyade bayram havasında bir kültüre dönüştürmüştür. Bu durum başta semt pazarları olmak üzere şehrin her tarafinda hissedilmektedir.

Bölgede farklı amaçlarla doğadan toplanarak kullanılan; 1 tohumsuz, 1 yarı parazit, 2'si tek çenekli ve 35'i çift çenekli olmak üzere toplam 40 familyaya ait 116 bitki türü belirlenmiştir. Yörede gıda ve tıbbi olarak kullanılan yabani/yabancı otların dahil oldukları familyalar Çizelge 1'de verilmiştir. Asteraceae (27 tür), Apiaceae (12 tür), Lamiaceae (10 tür), Liliaceae (7 tür), Rosaceae (7 tür), Fabaceae (6 tür) familyaları en fazla türle temsil edilen familyalardır (Çizelge 1). Bitki teşhislerinde ve Türkçe isimlendirilmelerinde Davis (1965-1985), Uluğ ve ark., (1993), Baytop (1989), Özer ve ark. (1999), Serin (2008), Özer ve ark. (2002) ve Anonim (2020a,b)'den yararlanılmıştır.

Çizelge 1. Hakkâri Yöresinde Gıda ve Tıbbi Amaçla Kullanılan Yabancı Otların Bulunduğu Familya Türü ve Sayısı

\begin{tabular}{|l|c|l|c|l|c|}
\hline Familya & Tür sayısı & Familya & Tür sayısı & Familya & Tür sayısı \\
\hline Amaranthaceae & 1 & Euphorbiaceae & 1 & Polygonaceae & 3 \\
\hline Anacardiaceae & 2 & Fabaceae & 6 & Portulacaceae & 1 \\
\hline Apiaceae & 12 & Gentianaceae & 1 & Primulaceae & 1 \\
\hline Araceae & 1 & Geraniaceae & 1 & Ranunculaceae & 1 \\
\hline Aristolochiaceae & 1 & Guttiferae & 3 & Rosaceae & 7 \\
\hline Asteraceae & 27 & Lamiaceae & 10 & Rubiaceae & 2 \\
\hline Boraginaceae & 2 & Liliaceae & 7 & Scrophulariaceae & 1 \\
\hline Brassicaceae & 3 & Loranthaceae & 1 & Solanaceae & 2 \\
\hline Campanulaceae & 2 & Malvaceae & 2 & Urticaceae & 1 \\
\hline Capparidaceae & 1 & Orchidaceae & 1 & Valerianaceae & 1 \\
\hline Chenopodiaceae & 1 & Papaveraceae & 1 & Violaceae & 1 \\
\hline Convolvulaceae & 1 & Plantaginaceae & 2 & Zygophyllaceae & 1 \\
\hline Cucurbitaceae & 1 & Pleurotaceae & 1 & & \\
\hline Equisetaceae & 1 & Poaceae & 1 & & \\
\hline
\end{tabular}

Bölgede tespiti yapılan bitkiler arasında endemik türlerin de olduğu tespit edilmiştir. Bölgede yoğun olarak tüketilen türlerin hemen herkes tarafından bilindiği (özellikle gıda amaçlı tüketilenler) fakat tıbbi amaçlarla kullanılan yabani türlerin sadece belli başlı kişiler (sağaltıcılar) dışında pek bilinmediği saptanmıştır. Halk tababetinde kullanılan bitkilerin ise genel olarak tek hastalıktan ziyade birçok hastalığın tedavisinde etkili olduğu ifade edilmiştir. Şifalı bitkiler tek başına kullanılabildiği gibi karışım halinde de kullanılabildikleri görülmüştür. Ayrıca bitkiler sade kullanılabildiği gibi süt, zeytinyağı, peynir, buğday ve bal gibi ürünlerle karıştıılarak da kullanılabilmektedir. Yörede farklı amaçlarla kullanılan bitkiler ve genel özellikleri yönünden derlenen bilgiler ve daha önce yapılan benzer çalışmalar (Baytop, 1999; Özer ve ark., 2002; Özer ve ark., 2004; Kaval, 2011; Uce ve Tunçtürk, 2014; Gül ve Dinler, 2016; Oğuz, 2016) dikkate alınarak Çizelge 2'de özetlenmiştir.

Çizelge 2. Hakkâri Yöresinde Gıda ve Tedavi Amaçlı Kullanılan Yabani/Yabancı Ot Türleri

Familya: Asteraceae

Latince ismi: Gundelia tournefortii L.

Türkçe ismi: Kenger
Familyası: Apiaceae

Latince isim: Heracleum persicum Desf.

Türkçe isim: Tavşancıl otu 


\begin{abstract}
Yöresel ismi: Kengir, Kereng
Kullanılan kısım: Tohum ve kök kısımları kullanılır.

Kullanılış Amacı ve Şekli: İştah açıcı, diş etlerini kuvvetlendirici, yorgunluk, böbrek ve karaciğer rahatsızlıklarını giderici, mide asidini önleyici, nezle ve soğuk algınlığına tedavi amaçlı kullanılır. Ayrıca çiçek ve yapraklarının ise yara iyileştirici özelliği bulunur. Bitkinin genç formu çiğ veya haşlanmış halde çeşitli yemeklerde (kahvaltılık, çorba, salata ve kızartmalık vb.) kullanılır. Aynı zamanda tohumları kahve yapımında ve kuruyemiş olarak da tüketilir. Salamura yapılarak kışın da kullanılır. Ayrıca toprak üstü aksamından kenger sakızı elde edilir.
\end{abstract}

\section{Familya: Polygonaceae}

Latince ismi: Rheum ribes $\mathrm{L}$.

Türkçe ismi: Yayla muzu

Yöresel ismi: Revas, Işgıın

Kullanılan kısım: Kök, yaprak ve gövdesi kullanılır.

Kullanılış Amacı ve Şekli: Şeker hastalığı, mide hazımsızlığı gidericisi, tansiyon dengeleyicisi ve iştah artırıcı gibi faydaları vardır. Bitkinin genç gövde kısmı ve yaprak sapı soyulduktan sonra çiğ olarak yenilir. Kurutulmuş kökler ise toz haline getirilip suda kaynatılarak ya da balla karıştırılıp tüketilmektedir. Ayrıca bitkinin yapraklarından mavi renk boya elde edilerek yün ve kilimlerde kullanıldığı belirtilmiştir.

\section{Familyası: Lamiaceae}

Latince isim: Mentha longifolia $\mathrm{L}$.

Türkçe isim: Yabani nane

Yöresel isim: Pünge, Püng

Kullanılan kısım: Yaprak ve gövdesi kullanılır.

Kullanılış Amacı ve Şekli Kadınlarda adet sancılarını giderici, bağırsak ve mide rahatsızlıkları, sindirim kolaylaştırıcı, balgam sökücü ve ağız kokusu giderici gibi faydaları vardır. Ayrıca iştah açıcı özelliğe de sahiptir. Yapraklar taze olarak kullanıldığı gibi kurutularak yemeklerde baharat olarak tüketilir.

\section{Familyası: Asteraceae \\ Latince isim: Scorzonera tomentosa $\mathrm{L}$.}

Türkçe isim: Dağ sakızı, Sakız otu

Yöresel isim: Benişti kaçki, Beniştereş, Benişti kevi

Kullanılan kısım: Kökleri kullanılır.

Kullanılış Amacı ve Şekli Ağrı dindirici ve çocuk sahibi olmayan kadınlarda kısırlık tedavisinde kullanılır. Bitkinin kökünden elde edilen sakız bez üzerine konulur ve yakı olarak kullanılır. Ayrıca bitkinin yaprakları çiğnenerek tüketildiğinde tokluk oluşturarak günlerce açlığa dayanılabilir.

\section{Familyası: Araceae}

Latince isim: Arum elongatum Steven

Türkçe isim: Yılanyastığı

Yöresel isim: Kari

Kullanılan kısım: Yaprak ve kökleri kullanılır.

Kullanılış Amacı ve Şekli: Bağırsak temizleyici, balgam sökücü, öksürük giderici ve ishal düzenleyici olarak kullanılır. Ayrıca bitkinin salgıladığı sütün ise yara iyileştirici özelliği de vardır. Bitkinin kurutulmuş kök kısımlarında 1 gramı kaynatılmış bir bardak suya konup yaklaşık 10 dakika bekledikten sonra içilir. Taze olarak tüketilmez, kurutulup kış aylarında yemeklere katılarak tüketilir.

\section{Familyası: Brassicaceae}

Latince isim: Lepidium latifolium $\mathrm{L}$.

Türkçe isim: Nujdar

Yöresel isim: Nojdar, Zarende

Kullanılan kısım: Yaprak ve kök kısımları kullanılır.

Kullanılış Amacı ve Şekli: Bitkinin yaprakları yara iyileştirici
Yöresel isim: Soh, Sove

Kullanılan kısım: Yaprak, gövde ve tohumları kullanılır.

Kullanılış Amacı ve Şekli: Süt arttırıcı, hazımsızlık, adet düzenleyici ve sakinleştirici olarak kullanılır. Bitki taze iken peynire tat ve aroma vermek için doğranarak içerisine konulur. Gövdesi ise soyularak turşuya katılır. Kurutulmuş yapraklar ortalama 20-30 gram 1 litre suda kaynatılarak yemeklerden önce içilmesi önerilir. Ayrıca sarılık hastalığına yakalanmış çocukların banyosunda bitki yaprakları 15-20 dakika suda kaynatılarak süzüp banyo suyu olarak kullanılmaktadır.

Familya: Apiaceae

Latince ismi: Chaerophyllum macrospermum (Willd. ex Sprengel)

Türkçe ismi: İri handok otu

Yöresel ismi: Mendi, Mend

Kullanılan kısım: Toprak üstü kısım kullanılır.

Kullanılış Amacı ve Şekli: Göğüs ve karın ağrılarını hafifletici ve gaz sancılarını giderici faydaları vardır. Bitki taze iken çiğ olarak yenildiği gibi peynir ve yemeklere katılarak da tüketilir. Ayrıca ilkbaharda toplanan bitkiler (özellikle genç gövdeler) salamura şeklinde hazırlanarak kış aylarında yemeklerde kullanılır. Bitkinin kurutulmuş yaprak ve sapları suda kaynatılıp suyu içilir.

Familyası: Asteraceae

Latince isim: Eryngium billardieri Delar.

Türkçe isim: Boğa dikeni

Yöresel isim: Tuske, Tüsi, Tosi

Kullanılan kısım: Yaprak gövde ve kökleri kullanılır.

Kullanılış Amacı ve Şekli: Cilt hastalıkları, diş iltihabı ve diş ağrısı dindirici olarak kullanılır. Köklerdeki özsuyu yara iyileştirici özelliğe sahiptir. Gövde kısmı taze olarak tüketildiği gibi kurutulmuş kök toz haline getirilerek hamur ve zeytinyağı ile karıştırıp iltihaplı ve ağrıyan bölgelere uygulanır.

Familyası: Plantaginaceae

Latince isim: Plantago major L.

Türkçe isim: İri Sinir otu

Yöresel isim: Belgehevizar

Kullanılan kısım: Yaprakları kullanılır.

Kullanılış Amacı ve Şekli: Yaş yaprakları ezilerek suyu ile beraber yanık, yara, çıban ve iltihaplanmaya karşı temizleyici özelliğe sahiptir. İdrar yolları hastalıklarına da faydalıdır. Ayrıca taze yaş yapraklarda sarmalar yapılarak tüketilmektedir.

Familya: Apiaceae

Latince ismi: Diplotaenia cachrydifolia Boiss.

Türkçe ismi: Köse otu

Yöresel ismi: Siyabo

Kullanılan kısım: Yaprak, gövde ve kök kısımları kullanılır.

Kullanılış Amacı ve Şekli: Romatizma, şeker hastalığı ve tansiyon dengeleyicisi olarak kullanılır. Ayrıca panzehir özelliği nedeniyle tüketildiğinde yılan vb zehirli hayvan isırmalarından çok fazla etkilenmez. Bitki genç iken haşlayıp tüketildiği gibi salamura yapılarak kış aylarında da tüketilmektedir. Yörede otlu peynirin kullanımında ve yağda kızartılarak birçok yemek çeşidinde kullanılmaktadır.

Familyası: Apiaceae

Latince isim: Ferula orientalis $\mathrm{L}$.

Türkçe isim: Çakşır otu

Yöresel isim: Kerkol, Hingedan, Heliz

Kullanılan kısım: Yaprak, gövde, kök ve bitki özsuyu kullanilır. 
ve hemoroid tedavisinde kullanılmaktadır. Ayrıca bitkinin kök kısımları kurutulduktan sonra mide ve egzama hastalıklarına faydalı olmaktadır. Bitkinin toprak üstü organları genellikle tedavi amaçlı olarak kullanılmaktadır.

Familyası: Convolvulaceae

Latince isim: Convolvulus betonicifolius Mill. subsp. peduncularis (Boiss.) Parris

Türkçe isim: Tarla sarmaşı̆̆

Yöresel isim: Lavlavk

Kullanılan kısım: Toprak üstü kısım kullanılır.

Kullanılış Amacı ve Şekli: Kabızlık, prostat, idrar sökücü, romatizma ağrı kesici ve yara temizleyici olarak faydalanılır. Suda kaynatılarak suyu içilir veya haşlanmış kısmı lapa şeklinde yara ve romatizmalı bölgelere konularak uygulama yapılır.

\section{Familyası: Asteraceae}

Latince isim: Arctium minus (Hill) Bernh.

Türkçe isim: Dulavratotu

Yöresel isim: Nisek, Nüsek

Kullanılan kısım: Yaprak ve gövdesi kullanılır.

Kullanılış Amacı ve Şekli: Eklem ve sırt ağrılarının tedavisinde kullanılmaktadır. Taze yaprakların yüzeyine zeytinyağı sürülüp ağrıyan bölgeye konulup bezle sarılır. Ayrıca bitki romatizma, prostat ve basur tedavisinde de etkili olmaktadır. Bitkinin genç gövdesi soyulup çiğ olarak da tüketilir.

\section{Familyası: Lamiaceae}

Latince isim: Teucrium chamaedrys L. subsp. sinuatum

Türkçe isim: Dalak otu

Yöresel isim: Celak

Kullanılan kısım: Toprak üstü kısım kullanılır.

Kullanılış Amacı ve Şekli: Mide rahatsızlıkları, migren, ateş düşürücü ve ağrı kesici gibi faydalı özellikleri vardır. Ayrıca kanser önleyici özelliği nedeniyle de kullanılmaktadır. Kurutulmuş bitkiler bitkisel çay olarak demlenip içilir.

Familyası: Malvaceae

Latince isim: Malva sylvestris L.

Türkçe isim: Ebegümeci

Yöresel isim: Nanê cücükê, Tolik,

Kullanılan kısım: Yaprak ve çiçekleri kullanılır.

Kullanılış Amacı ve Şekli: Öksürük, boğaz ağrısı, kabızlık, mide hastalıkları ve yanık tedavisinde kullanılır. Ayrıca bağırsak kurtlarını düşürme özelliği de bulunur. Bu amaçla kurutulmuş veya taze bitkiler bir avuç buğday ile karıştırılarak ay ışığında bir gece bekletildikten sonra aç karna yenilir. Yaralarda ve diş eti iltihabında bitki lapa haline getirerek, yara ve iltihaplı alana yarım saat bekletilerek uygulanır. Taze bitkiler çiğ olarak tüketildiği gibi yemek ve salatada da kullanılır.
Familyası: Lamiaceae
Latince isim: Teucrium polium L.
Türkçe isim: Acı yavşan
Yöresel isim: Giyayê Tal
Kullanılan kısım: Toprak üstü aksamı kullanılır.
Kullanılış Amacı ve Şekli: Karın ağrısı, adet sancısı, böbrek taşlarını düşürme, böbrek ağrılarında, ishal ve gaz giderici özelliği vardır. Mide hastalıkları tedavisinde kullanılır. Kurutulmuş bitkiler sıcak suda 5 dakika demlenerek aç karna içilir. Ayrıca kanser hastalığına da faydalıdır.

Familyası: Polygonaceae

Latince isim: Polygonum cognatum Meissn.

Türkçe isim: Madımak

Yöresel isim: Giyacücük

Kullanılan kısım: Yaprakları kullanılır.
Kullanılış Amacı ve Şekli: Nefes darlığı ve romatizma tedavisinde, gaz giderici ve bağırsak hastalıkların tedavisinde kullanılmaktadır. Bitki özellikle hemoroit tedavisinde faydalı olmaktadır. Kurutulmuş kökler toz haline getirilerek bal ile karıştırılıp tüketilir.

\section{Familyası: Primulaceae}

Latince isim: Primula auriculata L.

Türkçe isim: Çuha çiçeği

Yöresel isim: Sosin

Kullanılan kısım: Yaprak ve gövde kısımları kullanılır.

Kullanılış Amacı ve Şekli: Cilt yaralarını iyileştirici özelliği bulunur. Ayrıca bitkinin kanser tedavisinde etkili olmaktadır. Solunumu kolaylaştırmak (burun tıkanıklığı) için ezilmiş veya kurutulmuş bitki buruna çekilir. Taze iken yemeklere katılarak tüketilir.

Familyası: Capparidaceae

Latince isim: Capparis spinosa $\mathrm{L}$.

Türkçe isim: Kapari

Yöresel isim: Gebere

Kullanılan kısım: Meyveleri kullanılır.

Kullanılış Amacı ve Şekli: Kabızlık, idrar sökücü, basur, baş ağrısı, mide rahatsızlıkları ve karaciğer fonksiyonların düzenleyici özellikleri bulunur. Ayrıca cinsel gücü artırıcı etkisi de vardır. Yöresel bazı yemeklerde de kullanıldığı gibi erken dönemde meyveleri toplanıp turşusu da yapılır.

Familyası: Chenopodiaceae

Latince isim: Chenopodium foliosum L.

Türkçe isim: İnce sirken

Yöresel isim: Triye sor

Kullanılan kısım: Meyve ve yapraklar kullanılır.

Kullanılış Amacı ve Şekli: Karın ve mide ağrı giderici özelliği bulunur. Ayrıca öksürük kesmede etkilidir. Meyveler çiğ olarak tüketilmektedir. Yapraklar ise ortalama 10 dakika sicak suda kaynatıldıktan sonra günde iki kere tok karna içilir.

Familyası: Urticaceae

Latince isim: Urtica dioica $\mathrm{L}$.

Türkçe isim: Isırgan otu

Yöresel isim: Gezenk, Gezgerünk, Gezeng

Kullanılan kısım: Yaprak, gövde ve kök kullanılır.

Kullanılış Amacı ve Şekli: Kanser hastalığı, adet düzenleyici, romatizma ve eklem ağrılarına karşı etkili olduğu gibi saç dökülmelerine, saç köklerini güçlendirici ve canlılık kazandırma özelliği de bulunur. Bitkinin toprak üstü aksamı kaynatılmış suda 15-20 dakika bekletildikten sonra kullanılır. Ayrıca kemik erimesine karşı papatya ve karabaş otu ile bal ve suyla karıştırarak sabah-akşam aç karna içilmektedir.

Familyası: Amaranthaceae

Latince isim: Amaranthus retroflexus $\mathrm{L}$.

Türkçe isim: Kırmızı köklü horozibiği

Yöresel isim: Selmek

Kullanılan kısım: Yaprak ve tohumları kullanılır.

Kullanılış Amacı ve Şekli: Ateş düşürücü, tansiyon dengeleyici, mide rahatlatıcı ve romatizma hastalığı tedavisinde kullanılır. Tohumları suda 5-10 dakika kaynatarak, tok karna günde bir kere içilir. Taze yaprakları ise ezilerek merhem kıvamına getirilip romatizmalı bölgeye uygulanır. Ayrıca taze yapraklar salata ve yemeklerde kullanılır.

Familyası: Polygonaceae

Latince isim: Rumex ponticus E. H. L. Krause.*

Türkçe isim: Kıvırcık labada

Yöresel isim: Tırşok

Kullanılan kısım: Yaprak ve tohumları kullanılır. 
Kullanılış Amacı ve Şekli: İltihap sökücü, basur ve kabızlık tedavisinde kullanılır. Bitkinin taze yaprakları ezilerek iltihaplı bölgeye uygulanır. Ayrıca yapraklar suda yaklaşık 5 dakika kaynatıldıktan sonra suyu içilir. Basur hastalığı tedavisinde yapraklar lapa haline getirilerek uygulanır. Taze bitkilerden çeşitli yemekler de yapılır.

Familyası: Guttiferae

Latince isim: Hypericum helianthoides (Spech) Boiss.

Türkçe isim: Hoşap kızılotu

Yöresel isim: Giyaye sotena

Kullanılan kısım: Çiçekleri kullanılır.

Kullanılış Amacı ve Şekli Egzama ve yanık tedavisinde kullanılır. Kurutulmuş çiçekler zeytinyağı ile karıştırarak yanık ve egzama bölgesine doğrudan sürülür. Mide bulantısı, iştah açıcı, kabızlık ve gaz sancılarını giderici olarak da kullanılır. Kurutulmuş çiçekler suda yaklaşık 15 dakika kaynatıldıktan sonra süzülür, aç karna günde bir çay bardağı içilir.

\section{Familyası: Guttiferae}

Latince isim: Hypericum scabrum L.

Türkçe isim: Sarı kantaron

Yöresel isim: Giyaye birina

Kullanılan kısım: Çiçekleri kullanılır.

Kullanılış Amacı ve Şekli: Yara iyileştirmede etkilidir. Kurutulmuş çiçekler toz haline getirilerek yaralara konulur. Ayrıca adet sancısı dindirici özelliği de vardır. Kurutulmuş çiçekler suda ortalama 5 dakika kaynatılıp çay olarak içilir.

\section{Familyası: Brassicaceae}

Latince isim: Brassica nigra (L.) Koch.

Türkçe isim: Kara hardal

Yöresel isim: Xerdel

Kullanılan kısım: Çiçek ve tohumları kullanılır.

Kullanılış Amacı ve Şekli: Romatizma, Şeker hastalığı, baş ve diş ağrıları tedavisinde kullanılır. Kurutulmuş tohumlar zeytinyağı ile karıştırarak uygulama yapılır. Öksürük kesici, iştah açıcı ve hazmı kolaylaştırıcı özelliği de bulunur. Kurutulmuş çiçekler kaynar suda demlenerek içilir. Ayrıca burun tıkanıklığı içinde kurutulmuş çiçekler toz haline getirilerek buruna çekilir.

\section{Familyası: Fabaceae}

Latince isim: Astragalus oocephalus Boiss.

Türkçe isim: Ata geveni

Yöresel isim: Gogem, Giya pembü

Kullanılan kısım: Yaprak ve çiçekleri kullanılır.

Kullanılış Amacı ve Şekli: El ve ayaklarda oluşan çatlak ve yaraların tedavisinde kullanılır. Bitkinin yeşil aksamı 15-20 dakika suda kaynatılarak suyu süzülür, el ve ayaklar suyla yıkanarak tedavi edilir.

\section{Familyası: Fabaceae}

Latince isim: Trifolium pratense $\mathrm{L}$.

Türkçe isim: Çayır üçgülü

Yöresel isim: Fabaceae

Kullanılan kısım: Çiçek, yaprak ve dalları kullanılır.

Kullanılış Amacı ve Şekli: Damar açıcı, kan dolaşım hızlandırıcı, mide bulantısı giderici ve iştah açıcı özellikleri vardır. Taze ve kurutulmuş yeşil aksam suda yaklaşık 15 dakika kaynatılıp, suyu sabah-akşam aç karna içilir.

Familyası: Apiaceae

Latince isim: Smyrnium cordifolium Boiss.

Türkçe isim: Yabani kereviz

Yöresel isim: Xelendor

Kullanılan kısım: Gövdesi kullanılır.
Kullanılış Amacı ve Şekli: Guatr hastalığına karşı etkili olduğu gibi ateş düşürücü özelliği de vardır. Tohumlar suda yaklaşık 10 dakika kaynatılıp aç karna günde bir bardak içilir. Ayrıca taze yapraklar çiğ olarak tüketildiği gibi kurutulmuş şekilde yemeklerde ekşilik tadı vermek için baharat olarak da kullanılır. Taze yapraklardan sarma yapilır.

Familyası: Guttiferae

Latince isim: Hypericum lysimachioides Boiss.

Türkçe isim: Kantoron

Yöresel isim: Gula jan, Gulapiran

Kullanılan kısım: Çiçek, dal ve yaprakları kullanılır.

Kullanılış Amacı ve Şekli: Bağırsak kurt düşürücü ve uyku giderici özelliği vardır. Gastrit, ülser, terletici, sarılık, bel ağrısı, idrar sökücü ve ishal hastalıların tedavisinde de kullanılır. Kurutulmuş bitkiden çay yapılarak içilir. Yara iyileştirici özelliği de bulunur. Kurutulmuş bitkiler zeytinyağında ortalama 15 gün bekletildikten sonra yara bölgelerine sürülerek uygulanır.

Familyası: Papaveraceae

Latince isim: Papaver bracteatum Lindl.

Türkçe isim: Gelincik

Yöresel isim: Xaşxaş

Kullanılan kısım: Çiçek ve taç yaprakları kullanılır.

Kullanılış Amacı ve Şekli: Tansiyon ve kalp hastalıklarına faydalıdır. Ancak olgunlaşmamış meyveler tüketildiğinde uyuşukluk yapmaktadır. Bitkinin taze çiçek ve yaprakları çiğ olarak tüketilir.

Familyası: Scrophulariaceae

Latince isim: Verbascum speciosum Schrader

Türkçe isim: Sı̆̆ırkuyruğu

Yöresel isim: Giyaduv, Masicark

Kullanılan kısım: Çiçek ve yaprakları kullanılır.

Kullanılış Amacı ve Şekli: Şeker hastalığı ve romatizma tedavisinde kullanılır. Göğüs yumuşatıcı, balgam sökücü, bronşit, basur ve öksürük giderici özelliği de vardır. Şeker hastaları için yapraklar suda 15-20 dakika kaynatılıp, ayaklar içine konularak kullanılır. Ayrıca vücut yaraları içinde yapraklar lapa haline getirilerek yara bölgesine bırakılarak kullanılır.

Familyası: Fabaceae

Latince isim: Astragalus

yueksekovae Matthews.*

Türkçe isim: Geven

Yöresel isim: Gini, Güni

Kullanılan kısım: Kökleri kullanılır.

Kullanılış Amacı ve Şekli: Kanser hastalıklarının tedavisinde kullanılır. Kurutulmuş kökler toz haline getirilip bal ile karıştırılarak günde bir defa sabah aç karna bir kaşık yenilir. Ayrıca vücut direnci artırıcı ve kuvvetlendirici özellikleri de bulunur.

Familyası: Euphorbiaceae

Latince isim: Euphorbia grisophylla M. S. Khan*

Türkçe isim: Sütleğen

Yöresel isim: Şiri mahrı, Xoşil

Kullanılan kısım: Bitki öz suyu kullanılır.

Kullanılış Amacı ve Şekli: Kanser ve kabızlık hastalıklarına karşı etkilidir. Bitkiden akan sütün bir damlası bir bardak normal süt ile karıştırılarak içilir. Ayrıca bitki özsuyunun yara ve çatlaklara da iyi geldiği bilinir.

Familyası: Loranthaceae

Latince isim: Viscum album L.

Türkçe isim: Ökse otu

Yöresel isim: Dikane

Kullanılan kısım: Yaprak ve sapları kullanılır. 
Kullanılış Amacı ve Şekli: Astım, solunum yolu hastalıkları, nefes darlığı, baş ve diş ağrıları tedavisinde kullanılır. Kurutulmuş bitki parçaları toz haline getirilip bal ile karıştırılarak yenilir. Ayrıca suda kaynatılarak çay olarak da tüketilir.

\section{Familyası: Fabaceae}

Latince isim: Glycyrrhiza glabra L.

Türkçe isim: Meyan kökü

Yöresel isim: Mekük, Mikük

Kullanılan kısım: Kökleri kullanılır.

Kullanılış Amacı ve Şekli: Öksürük kesici, göğüs yumuşatıcı, balgam sökücü ve ağrı kesici özelliği bulunur. Ayrıca şeker hastalığı tedavisinde kullanılır. Kurutulmuş kökler toz haline getirilip, bal ve su ile karıştırılarak içilir.

\section{Familyası: Asteraceae}

Latince isim: Tripleurospermum microcephalum (Boiss.)

Bornm.).

Türkçe isim: Kavruk göde

Yöresel isim: Xizemok

Kullanılan kısım: Toprak üstü kısım kullanılır.

Kullanılış Amacı ve Şekli: Astım ve iltihaplara karşı kullanılır. Kurutulmuş bitki yaklaşık bir avuç kadar bir litre sütle karıştırarak sabah-akşam aç karna tüketilir.

\section{Familyası: Lamiaceae}

Latince isim: Nepeta nuda L. subsp. albiflora (Boiss.) Gams).

Türkçe isim: Karaküncü

Yöresel isim: Bareşa spi

Kullanılan kısım: Yaprak ve sapları kullanılır.

Kullanılış Amacı ve Şekli: Soğuk algınlığına karşı kullanılır. Kurutulmuş yapraklar suda demlenerek, sabah-akşam aç karna içilir. Ayrıca yara ve lekelere karşı da etkili olmaktadır. Kurutulmuş yapraklar toz haline getirerek zeytinyağı ile karıștırılarak sürülür.

\section{Familyası: Boraginaceae}

Latince isim: Anchusa azurea P. Mill.

Türkçe isim: Sığırdili

Yöresel isim: Gezrok, Mijmij, Mijmejok

Kullanılan kısım: Çiçek yaprak ve gövdesi kullanılır.

Kullanılış Amacı ve Şekli: Şeker hastalığı ve böbrek taşı düşürücü olarak gövdesi taze iken soğularak tüketilir. Yara ve dudak çatlaklarını iyileştirici özelliği vardır. Çiçekleri taze iken içindeki tatlımsı madde emilerek tüketilir. Astım tedavisinde yapraklar suda kaynatılarak aç karna günde bir bardak içilir. Kalp çarpıntılarına karşı ise çiçekleri kaynatılmış suda demlenerek günde bir çay bardağı aç karna içilir. Ayrıca sebzeli yemeklere katılarak tüketilir.

\section{Familyası: Rosaceae}

Latince isim: Amygdalus orientalis Mill.

Türkçe isim: Yabani badem

Yöresel isim: Hecibahok, Bahiv

Kullanılan kısım: Meyvesi kullanılır.

Kullanılış Amacı ve Şekli: Boğaz ağrıları tedavisinde kullanılır. Meyveler taze iken çiğ olarak tüketilir. Ayrıca kurutulmuş meyvelerden elde edilen yağlar kurt düşürücü, yara iyileştirici özellikleri de bulunur.

\section{Familyası: Asteraceae}

Latince isim: Achillea millefolium L.

Türkçe isim: Beyaz civanperçemi

Yöresel isim: Bewijana spi

Kullanılan kısım: Çiçekleri kullanılır.
Kullanılış Amacı ve Şekli: Kadınlarda adet sancı giderici ve adet düzenleyici olarak kullanılır. Ayrıca Kalp hastalıkları tedavisinde de etkilidir. Kurutulmuş yaprak ve saplar suda yaklaşık 10 dakika kaynatıldıktan sonra suyu içilir.

\section{Familyası: Solanaceae \\ Latince isim: Hyoscyamus niger L. \\ Türkçe isim: Kara banotu \\ Yöresel isim: Malğırab \\ Kullanılan kısım: Yaprakları kullanılır.}

Kullanılış Amacı ve Şekli: Ağrı kesici ve romatizma tedavisinde kullanılır. Ayrıca iltihaplı diş ağrılarına, nefes darlığına, mide hastalıklarına karşı da etkili olmaktadır. Bitki yapraklarını ezilerek merhem kıvamına getirilip ağrıyan bölgeye sürülür.

\section{Familyası: Asteraceae}

Latince isim: Centaurea pterocaula Trautv.

Türkçe isim: Çoruşbozan

Yöresel isim: Talkalüşk, Tali, Sermnik

Kullanılan kısım: Toprak üstü aksam kullanılır.

Kullanılış Amacı ve Şekli: Şeker hastalığı, yara iyileştirici, ishal düzenleyici özelliği bulunur. Kurutulmuş bitki kaynatılarak suyu içilir. Ayrıca kuru bitki ezilerek toz haline getirilip yara üzerine konulur.

Familyası: Lamiaceae

Latince isim: Phlomis pungens Willd.

Türkçe isim: Silvanok

Yöresel isim: Gula Bınevş

Kullanılan kısım: Toprak üstü aksamı kullanılır.

Kullanılış Amacı ve Şekli: Adet sancısı, rahim iltihabı ve karın ağrısı tedavilerinde kullanılır. Kurutulmuş bitkiler suda yaklaşık 20 dakika kaynatıldıktan sonra günde bir bardak içilir.

\section{Familyası: Asteraceae \\ Latince isim: Achillea filipendulina Lam. \\ Türkçe isim: Civamperçemi \\ Yöresel isim: Bewijan, Kulilka maran \\ Kullanılan kısım: Toprak üstü aksamı kullanılır.}

Kullanılış Amacı ve Şekli: Şeker ve kanser hastalığı, hipertansiyon, romatizma ve adet sancısı tedavisinde kullanılır. Kurutulmuş bitki çörekotu tohumu, karabaş otu, 1sırgan otu isteğe bağlı olarak bal veya su ile karıştırılarak kullanılır. Ortalama 100 gram bitki karışımı bir kavanoz süzme bal ile karıştırılarak her sabah bir çay kaşığı ya da bir su bardağına bir tatlı kaşığı kadar bitki karışımı atılıp günde bir bardak içilerek tüketilir. Ayrıca soğuk algınlığı, karın ve bağırsak ağrıları giderici özelliği de vardır.

Familyası: Aristolochiaceae

Latince isim: Aristolochia bottae Jaub. \& Spach.

Türkçe isim: Loğusa otu

Yöresel isim: Guhkıtık

Kullanılan kısım: Yaprak ve kökleri kullanılır.

Kullanılış Amacı ve Şekli: Yara ve kızarıklıklara karşı etkilidir. Taze kökler ezilip lapa haline getirilip yaralara sürülür. Vücuttaki kızarıklara ise taze kökler ezilip bal ile karıştırıp kullanılır. Ayrıca kurutulmuş yapraklar toz haline getirilip yaralara konulur.

\section{Familyası: Asteraceae}

Latince isim: Onopordum acanthium L.

Türkçe isim: Devedikeni

Yöresel isim: Kivara qelemoşk, Kivar

Kullanılan kısım: Tohum, yaprak ve gövdesi kullanılır. 
Kullanılıș Amacı ve Şekli: Kadınlarda adet düzensizliği ve rahim iltihabı tedavisinde faydalıdır. Ayrıca çocuk sahibi olmayan kadınlarda etkili olmaktadır. Kurutulmuş çiçekler çay gibi demlenerek kullanılır. Özellikle kısırlık tedavisinde 20 günden fazla kullanıldığı takdirde yumurtalıklara zarar verdiği belirtilmiştir.

Familyası: Asteraceae
Latince isim: Cichorium intybus L.
Türkçe isim: Yabani hindiba
Yöresel isim: Çeken, Şembélk, Kanéj, Kaniş
Kullanılan kısım: Toprak üstü kısımları kullanılır.
Kullanılış Amacı ve Şekli: Prostat kanseri, kabızlık, karın
ağrısı ve ishal tedavisinde kullanılır. Ayrıca egzama, mantar,
siğil, sedef ve cilt hastalıklarına karşı da etkilidir. Kurutulmuş
bitkiler çay gibi demlenip içilir.

\section{Familyası: Pleurotaceae}

Latince isim: Pleurotus eryngii var. ferulae (Lanzi) Sacc.

Türkçe isim: Yabani mantar

Yöresel isim: Karık, Kivark

Kullanılan kısım: Toprak üstü aksam kullanılır.

Kullanılış Amacı ve Şekli: Göz kaşıntısı tedavisinde etkilidir. Bitki ezilip özsuyu tülbentten geçirilerek uygulanır. Ayrıca gıda olarak ateşte kızartılarak ya da yemeklere katılarak tüketilir. Ekonomik değeri yüksek bitkilerdendir.

\section{Familyası: Asteraceae}

Latince isim: Centaurea triumfettii All.

Türkçe isim: Dağ gelin düğmesi

Yöresel isim: Talişk

Kullanılan kısım: Toprak üstü kısım kullanılır.

Kullanılış Amacı ve Şekli: Tansiyon düzenleyici ve şeker düşürücü olarak kullanılır. Ayrıca prostat ve ishal önleyici özelliği de bulunur. Kurutulmuş bitki çay gibi demlenerek içilir.

Familyası: Asteraceae

Latince isim: Lactuca serriola $\mathrm{L}$.

Türkçe isim: Eşek marulu

Yöresel isim: Spîbêr

Kullanılan kısım: Bitki sütü kullanılır.

Kullanılış Amacı ve Şekli: Kanser, mide hastalıkları, karın ağrıları ve tansiyon düşürücü özelliği var. Bitki sütü bir damla normal bir bardak sütle karıştırılarak tüketilir.

Familyası: Asteraceae

Latince isim: Tragopogon porrifolius L.

Türkçe isim: Yemlik

Yöresel isim: Spıng

Kullanılan kısım: Toprak üstü kısım kullanılır.

Kullanılış Amacı ve Şekli: Mide ağrıları, mide bulantısı iştah açıcı ve sindirim sistemi düzenleyicisi olarak kullanılır. Çiğ veya yemeklerde kullanılarak tüketilir. Ayrıca bitki özsuyu mantar hastalığına karşı da etkilidir.

\section{Familyası: Asteraceae}

Latince isim: Achillea biebersteinii Afan.

Türkçe isim: Sarı civanperçemi

Yöresel isim: Bewijan, Bevîjana küvî

Kullanılan kısım: Dallı çiçek demetleri kullanılır.

Kullanılış Amacı ve Şekli: Adet sancısı ve adet düzenleyici, iltihap temizleyici, idrar sökücü, ateş düşürücü, bağırsak fonksiyonlarını düzenleyici, baş ve boğaz ağrılarına karşı kullanılır. Kurutulmuş çiçekler çay gibi demlenip içilir. Kanamalarda kan durdurucu olarak faydalanılır. Ayrıca sinüzit ağrılarının dindirmesinde, bitki suda kaynatılarak oluşan
Kullanılış Amacı ve Şekli: Hemoroit tedavisinde ve ateş düşürücü olarak kullanılır. Kurutulmuş tohumlar ezilip zeytinyağı ile karıştırılarak hastalıklı bölgelere sürülür. Ayrıca kurutulmuş tohumlar balla karıştırılıp sabah-akşam aç karna kullanılır. Ayrıca gövdesi soyulup çiğ olarak tüketilir.

\section{Familyası: Campanulaceae \\ Latince isim: Campanula involucrata Aucher Ex A. DC. \\ Türkçe isim: Sarım çanı \\ Yöresel isim: Nüvijdara heqiqi \\ Kullanılan kısım: Yaprakları kullanılır.}

Kullanılış Amacı ve Şekli: Yara ve Cilt hastalıklarının (egzama vb) tedavisinde kullanılır. Taze yapraklar ezilip yaraya bırakılır. Kurutulmuş yapraklar ise ezilip zeytinyağı ile karıştırılarak kullanilır.

Familyası: Lamiaceae

Latince isim: Ziziphora clinopodioides Lam.

Türkçe isim: Kekik

Yöresel isim: Çatır

Kullanılan kısım: Yaprakları kullanılır.

Kullanılış Amacı ve Şekli: Mide ve göz rahatsızlıklarına, solunum yolu enfeksiyonları, yatıştırıcı, kan dolaşımı uyarıcı, kurt düşürücü ve cinsel gücü artırıcı özellikleri bulunur. Bitkisel çay olarak tüketilir. Taze yapraklar otlu peynire yemeklerde baharat olarak tüketilir..

Familyası: Rubiaceae

Latince isim: Galium tricornutum L.

Türkçe isim: Yoğurtotu

Yöresel isim: Dardurağa küvi

Kullanılan kısım: Toprak üstü kısım kullanılır.

Kullanılış Amacı ve Şekli: Romatizma hastalıkları, diş ve baş ağrıların tedavisinde faydalıdır. İştah açıcı özelliği de vardır. Yeşil aksam suda 10-15 dakika kaynatılır ve yarım çay bardağ kadar içilir.

Familyası: Solanaceae

Latince isim: Solanum alatum L.

Türkçe isim: Karagögündürme

Yöresel isim: Bacana küvi

Kullanılan kısım: Yaprakları kullanılır.

Kullanılış Amacı ve Şekli: Ateş düşürücü ve yara iyileştirici olarak kullanılır. Yaprakları ezilerek yara üzerine bırakarak uygulanır.

Familyası: Asteraceae

Latince isim: Scorzonera veratrifolia Fenzl.

Türkçe isim: Tekesakalı

Yöresel isim: Qopik, Palumink

Kullanılan kısım: Gövde ve yaprakları kullanılır.

Kullanılış Amacı ve Şekli: Diş ağrılarına, dişteki sarılık ve diş eti iltihabı temizleyici özelliği vardır. Taze yapraklar ezilip ağrıyan diş üzerine konulur. Ayrıca bitki sütü güneş yanıklarına karşı etkilidir. Bitkinin gövde kısmı taze olarak tüketildiğinde iştah açıcı özelliği de bulunur.

Familyası: Asteraceae

Latincesi Matricaria chamomilla L.

Türkçe isim: Tıbbi papatya

Yöresel isim: Beybün, Kulilkabayê

Kullanılan kısım: Çiçekleri kullanılır.

Kullanılış Amacı ve Şekli: Yatıştırıcı, terletici, gaz giderici, adet sancısı kesici, rahim iltihap sökücü, iştah açıcı, sinir sistemini düzenleyici, diş eti ve bademcik iltihaplarını önleyici, mide ve bağırsak yaralarını iyileştirici etkisi vardır. Kurutulmuş çiçekler bitkisel çay olarak tüketilir. Ayrıca saç dökülmelerine karşı ısırgan otu ile karıştırıp suyu ile saçlar yıkanır.. 
buharda baş kısmı bekletilerek tedavi edilir.

Familyası: Portulacaceae

Latince isim: Portulaca oleracea L.

Türkçe isim: Semizotu

Yöresel isim: Perpune

Kullanılan kısım: Toprak üstü kısım kullanılır.

Kullanılış Amacı ve Şekli: Bağırsak temizleyici, şeker hastalığı, kabızlık ve mide asit dengeleyici etkisi vardır. Taze olarak salata ve yemeklere katılarak tüketilir.

Familyası: Liliaceae

Latince isim: Fritillaria imperialis L.

Türkçe isim: Ters lale

Yöresel isim: Alal, Gülhırç,Güldexin

Kullanılan kısım: Toprak altı kök sağanları kullanılır.

Kullanılış Amacı ve Şekli: Genellikle süs bitkisi olarak kullanılır. Gıda veya tıbbi olarak tüketilmez. Ekonomik değeri yüksektir.

Familyası: Ranunculaceae

Latince isim: Ranunculus kochii Ladeb.

Türkçe isim: Kar çiçeği

Yöresel isim: Germuk

Kullanılan kısım: Yaprakları kullanılır.

Kullanılış Amacı ve Şekli: Taze olarak tüketildiği gibi kurutulmuş yapraklar yemeklere de konulur.

Familyası: Anacardiaceae

Latince isim: Pistacia khinjuk Stocks.

Türkçe isim: Bıttım

Yöresel isim: Gezan

Kullanılan kısım: Meyvesi kullanılır.

Kullanılış Amacı ve Şekli: Egzama ve mantar gibi cilt hastalıklarına iyi gelir. Ayrıca saç ve deri dökülmelerine, saçı yumuşatması ve rengini koyulaştırıcı özellikleri de bulunur.

Meyveleri ögütülerek kahve ve sabunda yapılır.

Familyası: Asteraceae

Latince isim: Helianthus tuberosus L.

Türkçe isim: Yer elması

Yöresel isim: Kırkıre, Seva ağ1

Kullanılan kısım: Yumrusu kullanılır.

Kullanılış Amacı ve Şekli: Şeker hastalığı romatizma ve anne sütü artırıcı gibi birçok faydalı özelliğgi bulunur. Çiğ olarak tüketildiği gibi haşlanarak sebze olarak da kullanılır.

\section{Familyası: Liliaceae}

Latince isim: Allium longicuspis Regel.

Türkçe isim: İt körmeni, Yabani soğan

Yöresel isim: Sirik, sir

Kullanılan kısım: Toprak üstü kısım kullanılır.

Kullanılış Amacı ve Şekli: Taze iken toplanıp doğranarak peynir ve yemeklere katılarak tüketilir.

\section{Familyası: Apiaceae}

Latince isim: Pimpinella anthriscoides Boiss. var. anthriscoides

Türkçe isim: Mesire otu

Yöresel isim: Alo

Kullanılan kısım: Toprak üstü kısım kullanılır.

Kullanılış Amacı ve Şekli: Taze iken yemeklere konulduğu gibi salamura yapılarak kışın da tüketilir. Ayrıca kırmızıbiber, karabiber ve kurutulmuş koyun midesi ile beraber belli bir süre bekletildikten sonra peynir mayası olarak kullanılır.

Familyası: Lamiaceae

Latince isim: Thymus kotschyanus Boiss. \& Hohen var. kotschyanus

Türkçe isim: Kekik

e-ISSN: 2148-2683
Familyası: Apiaceae

Türkçe isim: Kişniş

Yöresel isim: Gijnij

Kullanılan kısım: Tohumları kullanılır.

Kullanılış Amacı ve Şekli: Gaz ve hazımsızlığı giderici özelliği

vardır. Kurutulmuş tohumlar soğanla ezilip yağda salçayla

kavurup ekmek üzerine konularak yenir. Ayrıca kurutulmuş

tohumlar öğütülerek yemeklerde baharat olarak da tüketilir.

Familyası: Orchidaceae

Latince isim: Orchis palustris Jacq.

Türkçe isim: Çayır salebi

Yöresel isim: Şepırzek

Kullanılan kısım: Kök yumruları kullanılır.

Kullanılış Amacı ve Şekli: Kök yumruları salep mayası imalatında kullanılır. Birçok tıbbi özellikleri bulunur. Ekonomik değeri yüksektir. Aktarlarda satılır.

Familyası: Asteraceae

Latince isim: Centaurea glastifolia L.

Türkçe isim: Peygamber çiçeği

Yöresel isim: Tahlişk, Taltaliş

Kullanılan kısım: Toprak üstü kısım kullanılır.

Kullanılış Amacı ve Şekli: Prostat hastalığına iyi gelir. Kurutulmuş bitki suda kaynatılarak suyu içilir.

Familyası: Apiaceae

Latince isim: Ferulago angulata (Schlecht.) Boiss. subsp. angulata

Türkçe isim: Oluklu çakşır

Yöresel isim: Cevri

Kullanılan kısım: Toprak üstü kısım kullanılır.

Kullanılış Amacı ve Şekli: Genç sürgünleri doğranıp haşlandıktan sonra otlu peynir içerisine konulur.

Familyası: Liliaceae

Latince isim: Eremurus spectabilis M.Bieb.

Türkçe isim: Çiriş

Yöresel isim: Sitırk

Kullanılan kısım: Yaprak ve kökleri kullanılır.

Kullanılış Amacı ve Şekli: Bitkinin taze yaprak ve sürgünleri sebze ve yemeklerde kullanılır.

Familyası: Apiaceae

Latince isim: Smyrnium olusatrum L.

Türkçe isim: Yabani kereviz

Yöresel isim: Ğelendor

Kullanılan kısım: Toprak üstü kısım kullanılır.

Kullanılış Amacı ve Şekli: Nefes darlığı ve mide rahatsızlıklarına karşı etkilidir. Taze olan genç gövdesi soyularak tüketilir.

Familyası: Apiaceae

Latince isim: Anethum graveolens L.

Türkçe isim: Dereotu

Yöresel isim: Dardurağ

Kullanılan kısım: Toprak üstü kısım kullanılır.

Kullanılış Amacı ve Şekli: Kolesterol tedavisinde kullanılır.

Çiğ ya da suda kaynatarak suyu içilir. Ayrıca taze olarak salata ve cacıkta kullanılır. Kurutularak yemeklere tat vermek için baharat olarak da tüketilir.

Familyası: Asteraceae

Latince isim: Helichrysum arenarium subsp. Aucheri*

Türkçe isim: Yayla çiçeği

Yöresel isim: Gula zer, Sisin, Gulerink 
Yöresel isim: Çatıra kuvi

Kullanılan kısım: Toprak üstü kısım kullanılır.

Kullanılış Amacı ve Şekli: Nefes darlığı ve mide iltihabı tedavisinde kullanılır. Bitki çay olarak demlenip içilir. Ayrıca taze veya kurutulmuş halde yemeklerde baharat olarak tüketilir. Peynire tat ve aroma vermek için de kullanılır.

Familyası: Rosaceae

Latince isim: Rosa canina $\mathrm{L}$.

Türkçe isim: Kuşburnu

Yöresel isim: Şilandık

Kullanılan kısım: Meyveleri kullanılır.

Kullanılış Amacı ve Şekli: Öksürük, romatizma, grip, bronşit, şeker hastalığı ve idrar yolları rahatsızlıklarına iyi gelir. Ayrıca vücut direncini artırıcı özelliği vardır. Olgunlaşmış meyveler çiğ olarak yenildiği gibi reçel ve marmelatı da yapılır. Ayrıca kurutulmuş meyveler kış çayı olarak da tüketilir.

Familyası: Apiaceae

Latince isim: Falcaria vulgaris Bernh.

Türkçe isim: Orak otu

Yöresel isim: Bagelaşk

Kullanılan kısım: Toprak üstü kısmı kullanılır.

Kullanılış Amacı ve Şekli: Bıçak kesikleri ve yaralarının iyileştiricisi olarak kullanılır. Taze yeşil yapraklar ezilip yara üzerine bırakılıp bezle sarılır. Ayrıca yeşil yapraklar çiğ veya salataya konularak tüketilir.

\section{Familyası: Equisetaceae}

Latince isim: Equisetum fluviatile L.

Türkçe isim: Atkuyruğu

Yöresel isim: Giyamambel Giyagezik, Getgedok

Kullanılan kısım: Toprak üstü aksam kullanılır.

Kullanılış Amacı ve Şekli: Tansiyon, mide rahatsızlıklarına, karaciğer yağlanmasına, böbrek ve idrar yolu rahatsızlıklarına karşı etkilidir. Suda demlenerek çay olarak içilir.

\footnotetext{
Familyası: Valerianaceae

Latince isim: Centranthus longiflorus Stev. subsp. longiflorus

Türkçe isim: Mahmuz çiçeği

Yöresel isim: Soryaz

Kullanılan kısım: Yaprakları kullanılır.

Kullanılış Amacı ve Şekli: Yöresel yemeklerde taze veya kurutulmuş olarak tüketilir.
}

Familyası: Apiaceae
Latince isim: Foeniculum vulgare R. Mill.
Türkçe isim: Rezene
Yöresel isim: Rizyane
Kullanılan kısım: Tohum ve toprak üstü kısım kullanılır.
Kullanılıs Amacı ve Şekli: Yeni doğan çocuklarda karın ağrısı
giderici olarak kullanılır. Bitki tohumu ezilip toz haline getirilip
şeker ile karıştırarak temiz bir beze konulur. Bez emzik başı gibi
topuz haline getirilerek çocuklara emzirtilir. Ayrıca yemeklerde
baharat olarak da kullanılır.

\section{Familyası: Rosaceae}

Latince isim: Alchemilla hessii Rothm.

Türkçe isim: Aslanpençesi

Yöresel isim: Giyabirin

Kullanılan kısım: Yaprakları kullanılır.

Kullanılış Amacı ve Şekli: Kadın hastalıkları, iltihaplar ve kesik yaralarının tedavisinde kullanılır. Yapraklar ezilip lapa haline getirilerek yaralara konulur. Kurutulmuş yapraklar demlenerek çay olarak içilir.
Kullanılan kısım: Toprak üstü kısım kullanılır.

Kullanılış Amacı ve Şekli: Mide rahatsızlıkları ve bağırsak kurtlarını düşürücü faydaları bulunur. Öksürük, karın ağrısı, romatizma ve idrar yolları iltihabında düzenleyici özelliği de vardır. Kurutulmuş bitkiler suda kaynatılarak günde bir öğün içilir.

Familyası: Anacardiaceae

Latince isim: Rhus coriaria L.

Türkçe isim: Sumak

Yöresel isim: Sımak

Kullanılan kısım: Meyvesi kullanılır.

Kullanılış Amacı ve Şekli: Tansiyon, şeker hastalığı ve ağız içi yaralara karşı tedavi edici özelliği vardır. Ayrıca olgunlaşmış meyveler kurutulup, ögütülerek baharat olarak yemeklerde ve salatalarda kullanılır. Meyveler taze iken çiğ olarak da tüketilir.

Latince isim: Artemisia absinthium $\mathrm{L}$.

Familyası: Asteraceae

Türkçe isim: Acı pelin

Yöresel isim: Bevüjana kuvi, Giyabent

Kullanılan kısım: Toprak üstü kısmı kullanılır

Kullanılış Amacı ve Şekli: Şeker hastalığı, nefes darlığı, ateş ve kurt düşürücü, iştah açıcı ve mide rahatsızlıklarına karşı etkilidir. Kurutulmuş çiçek ve yapraklar suda kaynatılarak içilir.

\section{Familyası: Asteraceae}

Latince isim: Cirsium pubigerum (Desf.) DC. var. spinosum Pet.

Türkçe isim: Dere kangalı

Yöresel isim: Kivari avi

Kullanılan kısım: Kök ve gövdesi kullanılır.

Kullanılış Amacı ve Şekli: Vücuttaki şişkinliklerin giderilmesi için kullanılır. Genç ve taze olan gövde kısmı soyulup çiğ olarak tüketilir. Kök kısmı ezilip lapa haline getirilerek hastalıklı bölgeye uygulanır.

Familyası: Asteraceae

Latince isim: Tanacetum oltense (Sosn.) Grierson.).*

Türkçe isim: Pire otu

Yöresel isim: Kulilkabayê, Beybün, Bevüjan

Kullanılan kısım: Toprak üstü kısım kullanılır.

Kullanılış Amacı ve Şekli: Şeker hastalığı, karın ağrısı, adet sancısı ve rahim iltihap temizleyici özelliği bulunur. Kurutulmuş bitkiler sıcak suda 15 dakika demlenerek çay olarak günde iki kez tok karna tüketilir.

Familyası: Plantaginaceae

Latince isim: Plantago lanceolata L.

Türkçe isim: Dar Yapraklı Sinir otu

Yöresel isim: Giyamambel, Hevizara direj

Kullanılan kısım: Yaprakları kullanılır.

Kullanılış Amacı ve Şekli: Mide hastalıkları ve kanayan yaralara karşı kullanılır. Kurutulmuş yapraklar ezilip bal ile karıştırılarak tüketilir. Ayrıca taze yapraklar kanayan yaraların üstüne konularak uygulanır. Diş ağrısı ve iltihabına karşı da taze yapraklar ezilip üzerine konulur.

Familyası: Asteraceae

Latince isim: Anthemis austriaca Jacq.

Türkçe isim: Papatya

Yöresel isim: Papatya

Kullanılan kısım: Çiçekleri kullanılır.

Kullanılış Amacı ve Şekli: Soğuk algınlığına, öksürük, iltihap sökücü ve karın ağrıları giderici gibi faydalı özellikleri bulunur. Kurutulmuş çiçekler kış çayı olarak demlenip içilir. 
Familyası: Asteraceae

Latince isim: Cirsium haussknechtii Boiss.

Türkçe isim: İnce kangal

Yöresel isim: Kifar, Kelemok

Kullanılan kısım: Kök, gövde ve tohumları kullanılır.

Kullanılış Amacı ve Şekli: Diş temizleyici, ağız kokusu giderici, iştah açıcı, kırık ve çatlakların iyileştirici özelliği vardır. Bitkinin özsuyundan sakız yapılarak kısırlık tedavisinde yakı olarak kullanılır. Basur tedavisinde ise tohumlar ezilip balla karıştırarak tok karna günde bir defa tüketilir. Bitki taze iken gövdesi soyulup çiğ olarak yenilir.

Familyası: Lamiaceae

Latince isim: Salvia poculata Náb.

Türkçe isim: Öküzpörçüğü

Yöresel isim: Ezmangag

Kullanılan kısım: Yaprakları kullanılır.

Kullanılış Amacı ve Şekli: Taze yapraklarından sarma yapılır.

\section{Familyası: Rosaceae}

Latince isim: Malus sylvestris Mill.

Türkçe isim: Yabani elma

Yöresel isim: Sevik, Seve talk

Kullanılan kısım: Meyvesi kullanılır.

Kullanılış Amacı ve Şekli: Grip ve nezle hastalıklarında boğaz yumuşatıcı olarak kullanılır. Olgunlaşmış meyveler çiğ olarak yenildiği gibi hoşaf, reçel, komposto ve meyve suyu da yapılır. Ayrıca meyveler kış çayı olarak diğer bitkilerle karıştırılarak demlenip suyu içilir.

\section{Familyası: Rubiaceae}

Latince isim: Galium consanguineum Boiss.

Türkçe isim: Altın iplicik

Yöresel isim: Babelisk

Kullanılan kısım: Toprak üstü kısmı kullanılır.

Kullanılış Amacı ve Şekli: Basur hastalığına iyi gelir. Toprak üstü aksamı ezilerek hastalıklı bölgeye sürülür.

\section{Familyası: Asteraceae}

Latince isim: Echinops heterophyllus P.H. Davis

Türkçe isim: Mavi dünya

Yöresel isim: Bağuğe, Kelemok

Kullanılan kısım: Çiçek tablası kullanılır.

Kullanılış Amacı ve Şekli: Yeşil çiçek tablası temizlendikten sonra içi çiğ olarak tüketilir.

\section{Familyası: Violaceae}

Latince isim: Viola odorata L.

Türkçe isim: Mor menekşe

Yöresel isim: Binevşok

Kullanılan kısım: Yaprak, çiçek ve gövde kısımları kullanılır.

Kullanııș Amacı ve Şekli: Mide ve böbrek ağrılarının tedavisinde kullanılır. Çiçekleri taze iken çiğ olarak tüketilir. Ayrıca kurutulmuş bitki suda kaynatılarak suyu içilir.

\section{Familyası: Asteraceae}

Latince isim: Taraxacum montanum (C.A. Mey.) DC.

Türkçe isim: Karahindiba

Yöresel isim: Pitot

Kullanılan kısım: Bitki sütü kullanılır.

Kullanılış Amacı ve Şekli: Vücuttaki yara ve kesiklerin tedavisinde kullanılır. Ayrıca bitki sütünün göz kızarıklıklarını giderici özelliği bulunur.
Familyası: Malvaceae

Latince isim: Alcea hohenackeri Boiss.

Türkçe isim: Gülhatmi

Yöresel isim: Hero

Kullanılan kısım: Yaprak, gövde ve kökler kullanılır.

Kullanılış Amacı ve Şekli: Böbrek, üst solunum yolu enfeksiyonları, akciğer rahatsılıkları ve kadın hastalıkları tedavisinde kullanılır. İdrar yolu hastalıkları ve böbrek taşı düşürücü özelliği de vardır. Ayrıca migren ağrılarına karşı da faydalı olmaktadır. Kurutulmuş bitki kısımları demlenerek suyu içilir.

Familyası: Zygophyllaceae

Latince isim: Tribulus terrestris L.

Türkçe isim: Demir dikeni

Yöresel isim: Sedıdan

Kullanılan kısım: Toprak üstü kısım kullanılır.

Kullanılıs Amacı ve Şekli: Böbrek taşı düşürücü, ishal ve şeker hastalığ kaynatılarak suyu içilir.

Familyası: Lamiaceae

Latince isim: Prunella vulgaris L.

Türkçe isim: Acı Fesleğen

Yöresel isim: Sosin

Kullanılan kısım: Toprak üstü aksamı kullanılır.

Kullanılış Amacı ve Şekli: Balgam sökücü ve karın ağrıları giderici özelliği vardır. Kurutulmuş bitki kaynatılarak suyu içilir. Ayrıca genç sürgünleri peynir ve yemeklere katılır. Yemeklere lezzet ve aroma vermek için baharat olarak da tüketilir.

Familyası: Liliaceae

Latince isim: Allium scorodoprasum L.

Türkçe isim: Yabani soğan

Yöresel isim: Kurat

Kullanılan kısım: Toprak üstü kısım kullanılır.

Kullanılış Amacı ve Şekli: Tansiyon düşürücü, iştah açıcı gibi faydaları bulunur. Otlu peynir yapımında kullandığ gibi sebze ve baharat olarak da tüketilir.

Familyası: Campanulaceae

Latince isim: Michauxia laevigata Vent.

Türkçe isim: Kırtmaç

Yöresel isim: Şilgivik

Kullanılan kısım: Gövde kısmı kullanılır.

Kullanılış Amacı ve Şekli: Genç formda iken gövdesi soyulup çiğ olarak tüketilir.

Familyası: Asteraceae

Latince isim: Inula helenium L.

Türkçe isim: Andız otu

Yöresel isim: Peniruk

Kullanılan kısım: Toprak üstü kısım kullanılır.

Kullanılış Amacı ve Şekli: Basur hastalığı tedavisinde kullanılır. Taze yapraklar ezilip hastalıklı bölgeye sürülür. Ayrıca kurutulmuş bitki toz haline getirilerek vazelin ile birlikte hastalıklı alana sürülür.

Familyası: Boraginaceae

Latince isim: Alkanna froedinii Rech. F.

Türkçe isim: Havacıva otu

Yöresel isim: Mijmıjok, Güzrik

Kullanılan kısım: Toprak üstü kısım kullanılır.

Kullanılış Amacı ve Şekli: Karın ağrıları giderici özelliği vardır. Kökleri kaynatılarak suyu sabah-akşam bir bardak içilir. Ayrıca taze veya kurutulmuş olarak yemeklere katılarak tüketilir. Familyası: Liliaceae 
Latince isim: Alyssum pateri Nyár. subsp. pateri

Türkçe isim: Kanatlı kevke

Yöresel isim: Keselmehmut

Kullanılan kısım: Toprak üstü kısım kullanılır.

Kullanılıș Amacı ve Şekli: Mide ve böbrek rahatsızlıkları ve ishal giderici olarak kullanılır. Kurutulmuş bitki suda kaynatılarak suyu içilir.

\section{Familyası: Fabaceae}

Latince isim: Medicago sativa $\mathrm{L}$.

Türkçe isim: Yonca

Yöresel isim: Once, Hespist

Kullanılan kısım: Toprak üstü kısım kullanılır.

Kullanılış Amacı ve Şekli: Kesik ve yaralarda kanamayı durdurma etkisi bulunur. Bitki yeşil iken ezilerek lapa haline getirilip kesilen bölgeye konulur. Ayrıca kök kısmı peynir mayası yapımında kullanılır.

\section{Familyası: Geraniaceae}

Latince isim: Pelargonium quercetorum Agnew

Türkçe isim: Sardunya

Yöresel isim: Tolk, Tolke

Kullanılan kısım: Yaprak ve kökleri kullanılır.

Kullanılış Amacı ve Şekli: Çocuklarda bağırsak kurtları, boğaz rahatsızlıkları, baş ve boyun ağrıları ve deri yaralarının iyileştirici özelliği vardır. Kök kısmı suda kaynatılarak suyu içilir. Yaprakları sarma ve genç sürgünleri de sebze ve yemekler katılarak tüketilir.
Latince isim: Allium akaka S.G. Gmelin

Türkçe isim: Kuzukulağ

Yöresel isim: Guhbızın

Kullanılan kısım: Yaprakları kullanılır.

Kullanılış Amacı ve Şekli: Bitki taze ve kurutulmuş olarak peynir ve yemeklere katılarak tüketilir.

\section{Familyası: Fabaceae \\ Latince isim: Ononis spinosa L. \\ Türkçe isim: Kayışkıran kökü \\ Yöresel isim: Semisk \\ Kullanılan kısım: Yaprakları kullanılır.}

Kullanılış Amacı ve Şekli: Taş düşürücü, yara, egzama ve deri hastalıkların tedavisinde kullanılır. Kurutulmuş yapraklar kaynatılarak suyu içilir. Ayrıca genç yapraklar yemeklere katılarak tüketilir.

Familyası: Lamiaceae

Latince isim: Ocimum basilicum L.

Türkçe isim: Fesleğen

Yöresel isim: Mezre rihan, Rıhan

Kullanılan kısım: Toprak üstü kısım kullanılır.

Kullanılış Amacı ve Şekli: Mide rahatsızlıkları giderici ve yatıştırıcı, gaz giderici ve egzama hastalığının tedavisinde kullanılır. Ayrıca taze olarak salatalara katıldığı gibi kurutulan bitki yemeklerde baharat olarak tüketilir.
Familyası: Liliaceae

Latince isim: Ornithogalum arcuatum Steven.

Türkçe isim: Kurt kirişi

Yöresel isim: Gula spi, Hintirş, Şimli

Kullanılan kısım: Kökleri kullanılır.

Kullanılış Amacı ve Şekli: Balgam sökücü, iştah açıcı ve yorgunluk giderici faydaları vardır. Kurutulmuş kök ezilip toz haline getirilip isteğe bağlı olarak bal ya da kaynamış suya karıştırarak tüketilir.

\section{Familyası: Rosaceae}

Latince isim: Rubus caesius L.

Türkçe isim: Bögürrtlen

Yöresel isim: Tıriyi reş, Düdırk

Kullanılan kısım: Meyvesi kullanılır.

Kullanılış Amacı ve Şekli: Böbrek taşı düşürücü, kabızlık ve şeker hastalığı tedavisinde kullanılır. Olgunlaşan meyveler çiğ olarak yenildiği gibi reçel, komposto ve marmelatı da yapılarak tüketilir.

\section{Familyası: Poaceae}

Latince isim: Hordeum bulbosum L.

Türkçe isim: Boncuk arpa

Yöresel isim: Qamiş, Pivok

Kullanılan kısım: Yumruları kullanılır.

Kullanılış Amacı ve Şekli: Şeker hastalığı tedavisinde kullanılır. Yumrular suda kaynatılarak aç karna günde bir bardak içilir. Ayrıca Toprak üstü aksamı genç iken çiğ olarak tüketilir.

\section{Familyası: Rosaceae}

Latince isim: Pyrus syriaca Boiss. var. syriaca

Türkçe isim: Adi armut

Yöresel isim: Kurstık, Gırsık

Kullanılan kısım: Meyvesi kullanılır.

Kullanılış Amacı ve Şekli: Mide ağrıları ve balgam sökücü özelliği bulunur. Meyveler olgunlaştıktan sonra çiğ olarak tüketilir. Kurutulmuş meyveler hoşaf ve kompostosu yapılır.

Familyası: Liliaceae

Latince isim: Allium giganteum Regel

Türkçe isim: Başlı soğan

Yöresel isim: Lüş

Kullanılan kısım: Toprak üstü kısım kullanılır.

Kullanılış Amacı ve Şekli: Genç yapraklar doğranıp haşlandıktan sonra peynir ve yemekler katılarak tüketilir.

\section{Familyası: Cucurbitaceae}

Latince isim: Bryonia multiflora Boiss. \& Heldr

Türkçe isim: Ülüngür

Yöresel isim: Daraling

Kullanılan kısım: Kökleri kullanılır.

Kullanılış Amacı ve Şekli: Kabızlık, basur, mide sancısı giderici olarak kullanılır. Kökleri kaynatılarak suyu içilir veya lapa haline getirilip kabızlık giderici olarak kullanılır. 
Familyası: Gentianaceae

Latince isim Gentiana olivieri Griseb.

Türkçe isim: Afat otu

Yöresel isim: Asmin

Kullanılan kısım: Çiçekleri kullanılır.

Kullanılış Amacı ve Şekli: Migren, baş ağrısı, iştah açıcı ve ateş düşürücü olarak faydalanılır. Bitkinin kurutulmuş çiçekleri sıcak suda demlenerek çay olarak içilir.
Familyası: Rosaceae

Latince isim: Crataegus monogyna L.

Türkçe isim: Alıç

Yöresel isim: Guhişk

Kullanılan kısım: Meyveleri kullanılır.

Kullanılış Amacı ve Şekli: Sindirim bozukları, kalp ve damar tıkanıklığı, diş eti hastalığı ve tansiyon dengeleyici olarak kullanılır. Ayrıca stres ve depresyona iyi geldiği gibi zayıflatıcı özelliği de bulunur. Olgunlaşmış meyveler çiğ olarak tüketildiği gibi kışın da bitkisel çay olarak suyu içilir.

\subsection{Doğal Alanlar ve Tarımsal Ekosistemlerden Yabani/Yabancı Otlar Toplanırken Dikkat Edilmesi Gereken Hususlar ve Aşırı Bitki Toplamanın Etkileri}

Doğadaki biyoçeşitliğin korunması ve sürdürülebilirliğin sağlanması için bitki toplama çalışmalarında Bitki Genetik kaynaklarının toplanmasında izlenmesi gereken kurallar dikkate alınmalıdır (Özer ve ark., 1998). Bu çerçevede bitki toplayıcılarının topladıkları bitkileri çok iyi tanımaları, koruma altında olan bitkileri toplamamaları, soğanlı ve yumrulu bitkilerin soğanlarını ve yumrularını toplamamaları, çalı formdaki bitkileri kökten kesmemeleri gerekmektedir. Ancak bazı bölgelerde kışın yakacak olarak kullanılan çalı formdaki bitkileri kökten keserek toplamaktadırlar (Pala ve Dilmen, 2020). Ayrıca yöredeki bitki toplayıcılarının doğadaki bitki florası hakkında yeterli düzeyde bilgi sahibi olmadığı görülmüştür. Toplayıcıların, bölgede topladıkları bitkilerin statüleri (endemik, istilacı veya nesli tehlike altında olan tür vb) hakkında herhangi bir bilgi birikimlerinin de olmadığı saptanmıştır. Bu durum yöredeki biyolojik çeşitlilik açısından büyük bir sorun teşkil etmektedir. Buna yöredeki işsiz ve düşük gelirli ailelerin bitki toplamayı meslek haline getirmeleri de ilave edildiğinde; nesli tehlike altında olan bitki türlerinin aşırı ve kontrolsüz toplamaları sorununu daha da derinleştirmektedir. Zira bitki toplayıcıları çoğunlukla rastlanma sıklığı ve popülasyon seviyesi nispeten düşük ancak ekonomik değeri yüksek olan gıda ve tıbbi amaçla kullanılan bitki türleri ve endemik nitelik taşıyan soğanlı bitkileri toplayarak gelir elde etmektedirler. $\mathrm{Bu}$ nedenle özellikle ilkbahar aylarında bitki toplayıcılarının sayıları oldukça artmakta ve bölge dışından insanlar da yöreye akın etmektedir. Bilhassa elverişli coğrafyası ve zengin biyoçeşitliliği nedeniyle Yüksekova ilçesi ve bağlı mezralarında doğal bitki örtüsü daha da büyük tehdit altında olduğu görülmektedir. İnsan baskısı altında olması nedeniyle her geçen yıl toplanan bitkilerin popülasyon yoğunluklarının ciddi seviyede azaldığı yöre halkı tarafından da dile getirilmektedir. Dolayısıyla daha önce Özkahraman (2019) tarafından da belirtildiği üzere yörede etnobotanik nitelik taşıyan bitki türlerinin bölgede tehlike altında oldukları sonucuna varılmıştır.

Bitkilerin aşırı ve kontrolsüz olarak kökleriyle beraber toplanması alanda bitkinin neslinin devamını sağlayacak üreme organlarının oluşmasını (özellikle tohumla üreyen türlerde) temin edecek kadar bitkinin doğada kalmasına engel olmaktadır. Bölgede yapılan araştırmalar ve arazi sürveyleri sonucunda bitki örtüsündeki değişimin kısmen ekolojik faktörler (iklimsel değişiklikler) ve arazi kullanımında görülen değişimlerin de (doğal alanlar ve özellikle meraların tarım arazisi ve/veya başka amaçlarla kullanılması vb) rol oynadığı saptanmıştır. Dolayısıyla bölgede yoğun olarak yararlanılan türlerin yoğunluk ve rastlanma sıklığında görülen düşüşlerin en önemli sebepleri;

1.Aşırı ve bilinçsiz tarımsal faaliyetler, orman ve mera alanlarının tarıma açılması, yol ve madencilik çalışmaları, orman yangınları, erozyon vb hususlar,

2.Şehirleşmenin ve endüstrileşmenin getirdiği olumsuz etkileri,

3.Eğitim, yetişmiş insan ve denetim eksikliği,

4.Küresel ısınma ve iklim değişikliğinin olumsuz etkileri,

5.Karayolları ağının gelişmesi ile birlikte bitki toplayıcılarının istila edemediği doğal alanlara (yüksek yaylaları) kolayca ulaşabilmeleri,

6.Toplanan bitki organlarının bıçak veya makasla kesilmesi önerilirken bölgede bitki toplayıcılarının bel veya kürek gibi araç ve gereçler kullanarak bitkilerin kök veya soğan yapılarına zarar vererek toplamaları floradaki bitki popülasyonlarını ciddi anlamda zarara uğratmaktadır,

7.Diğer yandan bölgede çoğunlukla mera hayvancılığı yapıldığından, çayır-mera ve yaylalarda aşırı hayvan otlatmadan dolayı bölgedeki biyolojik çeşitlilik giderek azalmaktadır,

8.Hayvan otlatmanın dışında hayvanların kış beslenmesinde kullanılan yemlerde yazın çayır-mera alanlardaki bitkiler çiçeklenme döneminde biçilerek yem olarak değerlendirilmektedir. Bu durum da zaman zaman bitkiler tohum bağlamadan yapıldığından tür zenginliği veya popülasyon yoğunlukları önemli ölçüde azalmaktadır. 


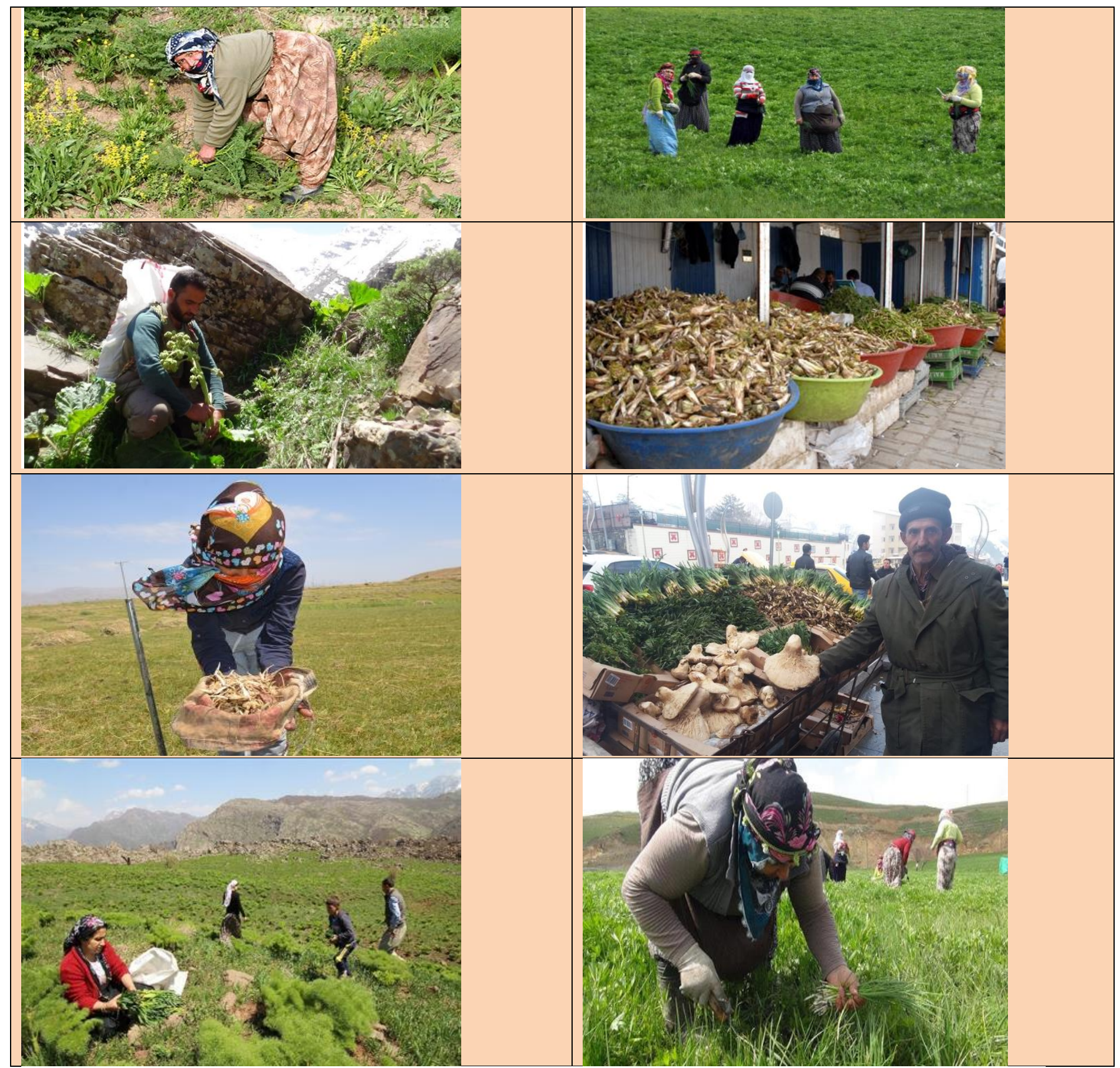

Şekil 1. Hakkâri'de tarım alanları ve doğal ekosistemlerden yabancı ot ve/veya yabani bitkilerin toplanması(Anonim, 2020c)

\section{3. Bölgede Sayıları Giderek Azalan ve Nesli Tehlike Altında Olan Bazı Yabani bitki Türleri}

Yapılan sürvey çalışmalarının sonuçları, kişisel deneyimler ve kırsal alanlarda yaşayan halkla yaptığımız görüşmeler neticesinde bölgede bitki çeşitliliğinde yıllar içerisinde büyük değişimlerin yaşandığı sonucuna varılmıştır. Yukarıda belirtilen sebeplerden kaynaklanan bu değişimin geri dönüşümü olmayan bir hal alma riski bulunmaktadır.

Nitekim toplayıcılar bu türlerin eskiden yerleşim yerlerinin çevresinde dahi bulunduğu ancak kontrolsüz ve aşırı toplanmaları nedeniyle sayılarının eskiye nazaran çok azaldığı hatta hiç kalmadığını ifade etmektedirler. Ayrıca çayır-meralarda dahi aşırı ve kontrolsüz toplanması sonucu bu türlerin popülasyonlarının giderek azaldığı ifade edilmiştir. Diğer bir değişim faktörü ise aşırı hayvan otlatılması nedeniyle bazı türler yok olurken, bazı türlerin ise özellikle hayvanlar tarafından yenilmeyen dikenli (geven gibi) bitkilerin daha fazla çoğalmasına neden olmaktadır. Ancak dikenli bir tür olan Kenger bitkisi hayvanlar tarafından yenilemediği halde insanlar tarafından kontrolsüz toplanması sebebiyle nesli tehlikede olan türlerden birisidir. Bu kapsamda bölge florasında yapılan sürvey ve mülakatlar sonucunda ekonomik getirisi fazla olan türlerin neslinin daha büyük tehlike altında olduğu tespit edilmiştir. Bu durumun yukarıda sıralanan nedenler yanında özellikle bölgedeki genç nüfusun ve işsizliğin giderek artması nedeniyle bitki toplayıcıların sayılarının gün geçtikçe artmasının bir sonucu olduğu düşünülmüştür. Dolayısıyla bölgenin halk kültüründe önemli bir yere sahip olan ve önemli bir ekonomik değere de sahip bulunan bitki türleri büyük tehlikelerle karşı karşıyadır. 
Yapılan sürvey, gözlem, mülakat ve literatür çalışmaları sonucunda bölgede en fazla toplanan ve nesli tehlike altında olan bitki türlerinin; Köse otu (Diplotaenia cachrydifolia), Yayla muzu (Rheum ribes), Kenger Gundelia tournefortii), Mendi (Chaerophyllum macrospermum), Mahmuz çiçeği (Centranthus longiflorus), Mesire otu (Pimpinella anthriscoides), Yabani soğan (Allium giganteum), Kekik (Thymus kotschyanus), Ters lale (Fritillaria imperialis), Çayır salep (Orchis palustris) ve Yabani mantar (Pleurotus eryngii) olduğu sonucuna varılmıştır.

\section{Sonuç}

Çalışma kapsamında yörede yapılan sürvey, mülakat ve literatür çalışmaları sonucunda; yöre halkı tarafından 40 familyaya ait 116 yabani/yabancı ot türünün farklı amaçlarla kullanıldığı saptanmıştır. Yöre halkıyla yapılan görüşmelerde ve arazi gözlemleri sonucunda Siyabo (Diplotaenia cachrydifolia), Revas (Rheum ribes), Mendi (Chaerophyllum macrospermum), Soryaz (Centranthus longiflorus), Kengir (Gundelia tournefortii) gibi bitkilerin (tohum, toprak üstü ve toprak altı kök kısımları) en fazla yararlanılan türler olduğu saptanmıştır. Ayrıca yörede gıda veya tedavi amaçlı kullanılan; Sirik (Allium giganteum), Catır (Thymus kotschyanus), Bevüjan (Tanacetum argyrophyllum), Nojdar (Lepidium latifolium), Hiro (Alcea flavovirens), Pünge (Mentha longifolia), Gezgezüng (Urtica dioica), Alo (Pimpinella anthriscoides), Sov (Heracleum persicum) ve Sipınk (Tragopogon buphthalmoides) gibi yabancı/yabani bitki türlerinin de nispeten yoğun bir kullanıma sahip oldukları görülmüştür. Yapılan sürveylerde insanlar tarafından rahatlıkla erişim sağlanan bölgelerde bu bitkilerin rastlanma sıklığı ve yoğunluklarının önemli ölçüde düştüğü belirlenmiştir. Ancak özellikle bölgenin yüksek yerlerinde bitki toplayıcılarının gidemediği alanlarda bu bitkilerin nispeten yüksek yoğunluklarda bulunabileceği ve bölgenin ekolojik çeşitliliğinin bir sonucu olarak buralarda başka türlerin (endemik nitelik taşıyan) çok sayıda bitki türünün de bulunabileceği ifade edilmektedir (Öztürk ve Özçelik, 1991; Yıldırım, 1991;Vural ve ark., 1997; ; Baytop, 1999; Ertuğ, 2000; Şimşek ve ark., 2002; Arık, 2003; Özgen ve ark., 2004; Türkoğlu ve ark., 2006; Gencay, 2007; Yeşil, 2007; Yapıcı ve ark., 2009; Alpaslan, 2012; Mükemer, 2013; Vural, 2014; Özaslan ve ark., 2016). Dolayısıyla en azından bu bölgeler insanların kontrolsüz erişimine açılmaması bölgenin biyolojik zenginliğinin korunarak gelecek nesillere aktarılması açısından önem taşımaktadır.

Bölgede başta sosyo-ekonomik faktörler olmak üzere insanların doğal bitki örtüsü üzerinde; aşırı otlama, aşırı bitki toplama, ormanların yok edilmesi ve yanlış tarımsal faaliyetler gibi tehditler yörenin zengin ekolojisine büyük zararlar vermektedir. Ayrıca bölgenin biyolojik çeşitliliğini tehdit eden önemli bir faktörün de gün geçtikçe sayısı artmakta olan maden ocakları olduğu belirtilmektedir (Kaval, 2011). Diğer yandan bölgede toplanarak kullanılan yabani bitkilerin popülasyon yoğunlukları düștükçe ekonomik değeri arttığından bitki toplayıcıların sayısını da özellikle ilkbahar aylarında arttırmaktadır. Bu durum toplayıcıların daha geniş alanlara yayılmasına neden olmakta ve özellikle siyabo, kengir, revas ve mendi gibi bitkiler nerede ise tamamen toplanmaktadır. Bitkiler çiçek açıp, tohum bağlanmasına firsat verilmeden bütün bitki kısımlarının sökülüp toplanmaktadır. Bu nedenle bölge doğal bitki örtüsü giderek zayıflamakta veya birçok bitki türü yok olmayla karșı karşıya kalmaktadır. Ayrıca bölgede mera hayvancıllığından kaynaklanan aşırı otlama da bölgedeki endemik türler başta olmak üzere bitki erozyonuna neden olmaktadır. Hakkari yöresiyle özdeşleşen ağlayan gelin (ters lale) ve sosin çiçeği gibi soğanlı endemik türler doğal yaşam alanlarının bozulması nedeniyle nesli tehlike altında olan diğer bazı endemik bitki türleridir (Akçiçek ve Vural, 2007; Manvelidze ve ark., 2009; Balkaya ve ark., 2015; Çelikel, 2015; Nohutçu ve ark., 2019).

Çalışma sonuçları bölgede ekonomik değere sahip bitki türlerinin durumu ve korunmasına yönelik detaylı çalışmaların yapılması, ayrıca en azından belirli türlerin kültüre alınmasına yönelik araştırmaların yapılması gerektiğini ortaya koymaktadır. Ayrıca bölgede soğanlı türlerin (Lilium spp.) biyolojik ve ekolojik özelliklerine yönelik bilimsel araştırmalar artırılmalı, bu türlerin korunması, neslini devam ettirebilmesi ve mevcut popülasyonun zarar görmemesi için başta bitki toplayıcıları olmak üzere yöre halkının konunun önemi hakkında eğitim ve seminerler verilerek bilinçlendirilme çalışmaları yapılmalıdır. Ayrıca endemik olan türlerin neslini korumak amacıyla bitki örnekleri (ex-situ muhafaza) botanik bahçelerinde çoğaltılmalı ve/veya tohumlarının gen bankalarında muhafazası yoluna gidilmelidir. Ya da in vitro muhafaza tekniklerinden yararlanılarak, DNA depolanmas1, polen depolanmas1, dondurarak muhafaza veya yapay tohumlama vb yöntemler kullanılarak gen muhafaza çalışmaları yürütülmelidir (Balkaya ve Yanmaz, 2001; Nybom, 2004; Tan, 2013; Çelikel, 2014; Özen ve ark., 2016).

Sonuç olarak; genetik kaynakların korunması ülkelerin geleceği ve ekosistem dengesinin korunması açısından oldukça önemli bir unsur olduğu ifade edilmiştir (Özer ve ark., 2001; Özen ve ark, 2016). Bu nedenle ülkemizin mevcut biyolojik kaynaklarının korunması, doğal ekosistemlerin korunmasından geçmektedir. Özellikle de biyolojik çeşitliliği zengin, yüksek sayıda endemik tür barındıran bölgelerde bölgeye has koruma politika ve/veya statüleri oluşturarak biyoçeşitliliğin ve doğal kaynakların sürdürülebilirliği sağlanılabilir (Önen, 2010; Önen ve Özcan, 2010; Özen ve ark, 2016; Demir ve Çelikel, 2017).

$\mathrm{Bu}$ çerçevede çalışma alanında biyolojik çeşitliliğin sürdürülebilir şekilde korunması için insanlar tarafından yoğun olarak toplanan ekonomik değeri yüksek bitkilerin gelecek nesillere aktarılabilmesi ekolojik ve ekonomik açıdan büyük önem arz etmektedir. $\mathrm{Bu}$ amaçla bir yandan gerekli yasal tedbirlerin alınması, bölgedeki biyolojik çeșitliliğin ortaya konulması için geniş kapsamlı araştırma faaliyetlerinin yapılması ve mevcut gen kaynaklarının (özellikle endemik bitki türlerin) korunmasına yönelik projelerin desteklenmesi vb çalı̧̧malara ihtiyaç duyulurken, diğer yandan yöre halkına yönelik; doğal kaynakların korunması, doğal floradaki bitkileri tanıma, toplama ve muhafazasının yanı sıra mera yönetim sisteminin önemi vb konularda eğitim çalışmalarının yapılmasının bölge florasının korunması için elzem olduğu sonucuna varılmıştır. 


\section{Kaynakça}

Akçiçek, E., \& Vural, M. (2007). Kumalar dağı (Afyonkarahisar)’nın endemik ve nadir bitkileri, Balıkesir Üniversitesi Fen Bilimleri Enstitüsü Dergisi 9(2), 78-86.

Alpaslan, Z. (2012). Ergan Dağı (Erzincan)'nın Etnobotanik Özellikleri. (Yayınlanmamış Yüksek Lisans Tezi) Erzincan Üniversitesi, Fen Bilimleri Enstitüsü Biyoloji Anabilim Dalı Erzincan.

Anonim (2019). https://news.mongabay.com/2016/05/many-plants-world-scientists-may-now-answer/(Erişim tarihi: 27.12.2019).

Anonim (2020a). https://www.turkiyebitkileri.com/tr(Erişim tarihi: 16.01.2020).

Anonim (2020b). https://www.bizimbitkiler.org.tr(Erişim tarihi: 16.01.2020).

Anonim (2020c). https://www.yuksekovahaber.com.tr/haber/kadinlar-daglara-dogru-7698.htm(Erişim tarihi: 16.01.2020).

Arık, M. (2003). Korkut (Muş) İlçesi ve Köylerinin Faydalı Bitkileri, (Yüksek Lisans Tezi) Yüzüncü Yıı Üniversitesi, Fen Bilimleri Enstitüsü, Biyoloji Anabilim Dalı, Van.

Arslan, N. (2014). Endemik Tibbi Bitkilerimiz. II. Tıbbi ve Aromatik Bitkiler Sempozyumu, Bildiriler Kitab1 (s., 9-21) Yalova, Türkiye.

Balkaya, A., \& Yanmaz, R. (2001). Bitki genetik kaynaklarının muhafaza imkanları ve tohum gen bankalarının çalışma sistemleri. Ekoloji Çevre Dergisi. 10(39):25-30.

Balkaya, A., Duman, İ., Engiz, M., Ermiş, S., Onus, N., Özcan, M., Çelikel, F., Demir, İ., Kandemir, D., \& Özer, M. (2015). Bahçe bitkileri tohumluğu üretimi ve kullanımında değişimler ve yeni arayışlar. Türkiye Ziraat Mühendisliği VIII. Teknik Kongresi. (s., 985-1110) Ankara, Türkiye.

Baytop A. (1989). Türkiye'nin Tıbbi ve Zehirli Bitkileri. İstanbul Üniversitesi Yayın No: 3560 Gençlik Matbaası, İstanbul.

Baytop, T. (1999). Türkiye'de Bitkiler İle Tedavi Geçmişte ve Bugün, Baskı: II, Nobel Kitabevi İstanbul.

Bramwell, D. (2002). How many plant species are there. Plant Talk, 28, 32-34.

Çakmak, N. M. (2008). Biyolojik Çeşitliliğin Hukuken Korunması ve Kamu Yararı, Ankara Üniversitesi Hukuk Fakültesi Dergisi, 57(1),133-166.

Çelikel, F. G. (2014). Doğal çiçek soğanları. Süs Bitkileri Ders Notları, Ondokuz Mayıs Üniversitesi, Ziraat Fakültesi, Bahçe Bitkileri Bölümü, Samsun.

Çelikel, FG. (2015). Süs bitkilerinde tohumluk (tohum, fide, fidan, soğan) üretimi ve kullanımı. SÜSBİR Dergisi. 2015 (3), 32-33.

Davis, P.H. (1985-1988). Flora Of Turkey And The East Aegean Islands. Vol. I-X Edinburgh Üniv. Press.

Demir, S., \& Çelikel, F.G. (2017). Türkiye'nin Nesli Tehlike Altında olan Lilium sp. Türleri, Türk tarım-gıda bilim ve teknoloji dergisi, 5(13), 1796-1801.

Ertuğ, F. (2000). An Ethnobotanical Study in Central Anatolia (Turkey ), Economic Botany, 54 (2), 155-182.

Gençay, A. (2007). Cizre (Şırnak)'nin Etnobotanik Özellikler. (Yüksek Lisans Tezi) Yüzüncü Yıl Üniversitesi, Fen Bilimleri Enstitüsü, Van.

Gül, V., \& Dinler, B. S. (2016). Kumru (Ordu) Yöresinde Doğal Olarak Yetişen Bazı Tıbbi ve Aromatik Bitkiler. Süleyman Demirel Üniversitesi Ziraat Fakültesi Dergisi 11 (1),146-156.ISSN 1304-9984

Güner, A., Aslan, S., Ekim, T., Vural, M., \& Babaç, M.T. (2012). Türkiye Bitkileri Listesi (Damarlı Bitkiler), Nezahat Gökyiğit Botanik Bahçesi ve Flora Araştırmaları Derneği Yayını, İstanbul.

Güner, A. (2012). Türkiye Bitkileri Listesi (Damarlı Bitkiler), ANG Vakfı / Nezahat Gökyiğit Botanik Bahçesi.

Karaer, F., Kutbay, H. G., \& Terzioğlu, S. (2015). Türkiye'nin istilacı yabancı bitki biyoçeşitliliği, tehdit faktörleri ve alınması gerekli tedbirler Türk Herboloji Dergisi, 18(1-2), 24-32.

Karagöz A., Zencirci, N., Tan, A., Taşkın, T., Köksel, H., Sürek, M., Toker, C., \& Özbek, K. (2010). Bitki genetik Kaynaklarının Korunması ve Kullanımı, Türkiye Ziraat Mühendisliği VII. Teknik Kongresi, (s., 155-177) Ankara, Türkiye.

Kaval, İ. (2011). Geçitli (Hakkâri) ve Çevresinin Etnobotanik Özellikleri. (Yüksek Lisans Tezi), Yüzüncü Yıl Üniversitesi Fen Bilimleri Enstitüsü Biyoloji Anabilim Dalı, Van.

Kençe, A. (1991). Biyolojik çeşitlilik. Çevre sorunları üzerine, Türkiye Çevre sorunları Vakfı Yayınları, (S., 234-248), Kavaklıdere, Ankara.

Manvelidze, Z., Eminağaoğlu, Ö., Memiadze, N., Kharazishvili, D. (2009). Species Diversity and Conservation Priorities for Endemic Plants of Georgian-Turkish Transboundary Zone in the West Lesser Caucasus Corridor. Nugzar Zazanashvili, David Mallon (eds). Status And Protection Of Globally Threatened Species In The Caucasus. Tbilisi 2009 P:199-205.

Mükemre, M. (2013). Konalga, Sırmalı, Dokuzdam köyleri (Çatak-Van) ve çevrelerinin etnobotanik özellikleri. (Yüksek Lisans Tezi), Yüzüncü Yıl Üniversitesi Fen Bilimleri Enstitüsü Biyoloji Anabilim Dalı, Van.

Nohutçu, L., Tunçtürk, M., \& Tunçtürk, R. (2019). Yabani Bitkiler ve Sürdürülebilirlik, Yüzüncü Yıl Üniversitesi Fen Bilimleri Enstitüsü Dergisi, 24(2), 142-151.

Nybom, H. (2004). Comparison of different nuclear DNA markers for estimating intraspecific genetic diversity in plants. Mol. Ecol. 13(5), 1143-1155.

Oğuz, F. (2016). Yüksekova (Hakkâri) Yöresinde Halk Tababetinde Kullanılan Bitkiler ve Kullanım Alanları, (Yüksek Lisans Tezi), Yüzüncü Yıl Üniversitesi Fen Bilimleri Enstitüsü Bitki Koruma Anabilim Dalı, Van.

Önen, H., \& Özcan, S. (2010). İklim Değişikliğine Bağlı Olarak Yabancı Ot Mücadelesi. Ed. SAYILI, M. 2010. İklim Değişikliğinin Tarıma Etkileri ve Alınabilecek Önlemler. T.C. Kayseri Valiliği İl Tarım Müdürlüğü Yayın No:2, 336-357, Fidan Ofset, Kayseri.

Önen, H. (2010). Küresel Isınma ve Biyolojik Çeşitlilik. Ed. Serin, Y. 2010. Küresel İklim Değişimine Bağlı Sürdürülebilir Tarım, Cilt III Teknik Eleman Eğitimi Chapter, Erciyes Üniversitesi Yayın No:177, Erciyes Üniversitesi Seyrani Ziraat Fakültesi Yayın No:1, S:134-154, Fidan Ofset, Kayseri. 
Özaslan, C., Farooq S., \& Önen, H. (2016). Ruthless Use Can Pose Extinction Risk To Gundelia (Gundelia Tournefortii L.) In Southeastern Anatolia Region Of Turkey, VII International Scientific Agriculture Symposium, (p., 629-630) Bosnia and Herzegovina.

Önen H., Farooq S., \& Gunal, H. (2016). Impacts of invasive plants on ecosystem functioning and biodiversity in terrestrial ecosystems. In: COST Action ES1104 White Paper on the Restoration of Drylands.

Onen, H., Farooq, S., \& Ozaslan, C. (2017). "Do management efforts and vegetation succession affect the naturalisation success and vegetation dynamics of Common Ragweed in Turkey?", in: Proceedings of 7th ESENIAS Workshop with Scientific Conference(p., 88) Sofia

Özen, F., Aka, G.E., \& Aksoy, Ö. (2016). Genetic diversity and conservation strategies of some Lilium candidum L. population in Turkey. Bangladesh Journal of Botany, 45(1), 133-141.

Özer, Z., Tursun, N., Önen, H., Uygur, F.N. \& Erol, D. (1998). Herbaryum Yapma Teknikleri ve Yabancı Ot Teşhis Yöntemleri. Gaziosmanpaşa Üniversitesi Ziraat Fakültesi Yayınları No:22 Kitap Serisi No:12 TOKAT

Özer, Z., Önen, H., Tursun, N., \& Uygur, F. N. (1999). Türkiye’nin Bazı Önemli Yabancı Otları. Gaziosmanpaşa Üniversitesi, Ziraat Fakültesi Yayınları, No:38 Kitap seri No:16, Tokat.

Özer, Z., Kadığlu, İ., Önen, H., \& Tursun, N. (2001). Herboloji (Yabancı Ot Bilimi) Gaziosmanpaşa Üniversitesi Ziraat Fakültesi Yayınları No:20 Kitap Serisi No:10, 3. Bask1, TOKAT

Özer, Z., Tursun, N., \& Önen, H. (2002). Yabancı Otlarla Sağlıklı Yaşam, 4 Renk Yayın Tanıtım Matbaacılık Ltd. Şti. No: 85/7 İskitler/ Ankara.

Özer, Z., Elibüyük, E.A., Önen, H., \& Tekelioğlu, O. (2004). Yabancı Otların Beslenmede ve Sağlıktaki Rolü. Ed. Toygar, K., 2004. Otların Beslenmede ve Sağlıktaki Rolü. Türk Halk Kültürünü Araştırma ve Tanıtma Vakfı Yayınları, Ankara.

Özgen, U., Kaya, Y., \& Maksut, C., (2004). Etnobotanical studies in The Villages of The District of ILICA (Erzurum), Turkey, Economic Botany 58(4), 691-696.

Özkahraman, E. (2019). Bihar ü Pincar, https://www.yuksekovahaber.com.tr/yazi/bihar-u-pincar-4622.htm

Öztürk, M., \& Özçelik, H. (1991). Doğu Anadolu’nun Faydalı Bitkileri. Siskav, Siirt İlim, Spor, Kültür ve Araştırma Vakfı, Ankara.

Pala ve Dilmen (2020). Savucak Dağı kışlak alanlarında süneye (Eurygaster integriceps Put.) konukçuluk eden yabancı otlar. EJONS International Journal on Mathematics, Engineering and Natural Sciences, 4(13), 60-66.

Polat, R., Selvi, S., Çakılcıoglu, U., \& Açar, M. (2012). Bingöl semt pazarlarında satılan yabani bitkilerin etnobotanik açıdan incelenmesi, Biological Diversity and Conservation, 5(3), 155-161.

Serin, Y. (2008). Türkiye'nin Çayır Mera Bitkileri. T.C. Tarım ve Köyişleri Bakanlığı Tarımsal Üretim ve Geliştirme Genel Müdürlüğü, Ankara.

Şimşek, I., Aytekin, F., Yeşilada, E., \& Yıldırımlı, Ş. (2002). Anadolu'da halk arasında bitkilerin kullanılış amaçları üzerinde etnobotanik bir çalışma. Bitkisel İlaç Hammaddeleri Toplantısı, Bildiriler. (s., 434-457), Eskişehir, Türkiye.

Tan, A. (2013). Bitki Genetik Kaynakları Çalışmaları, Ege Tarımsal Araştırma Enstitüsü Müdürlüğü, Tanıtım Broşürü No:3.

Turan, L. (2007). Biyolojik çeşitlilik ve Türkiye. TUBİTAK.

Türkoğlu, İ., Civelek, S., \& Kürşat, M. (2006). Gözeli ve Kavak Ovalarında (Elazı̆̆) Etnobotanik Bir Araştırma. Fırat University Journal of Science and Engineering, 18, 7-19.

Uce, İ., \& Tunçtürk, M. (2014). Hakkâri’ de Doğal Olarak Yetişen ve Yaygın Olarak Kullanılan Bazı Yabani Bitkiler, Biyoloji Bilimleri Araştırma Dergisi 7 (2), 21-25. ISSN: 1308-3961, E-ISSN: 1308-0261.

Uluğ, E., Kadığlu, İ., \& Üremiş, İ. (1993). Türkiye’nin Yabancı Otları ve Bazı Özellikleri. T.K.B. Adana Zirai Mücadele Araştırma Enstitüsü, Yay. No: 78, 513, Adana.

Vural, H. (2014). Ağız ve Diş Sağlığında Kullanılan Bitkiler Üzerinde Farmakognozik Çalışmalar, (Yüksek lisans tezi), Erciyes Üniversitesi Eczacılık Fakültesi Farmakognozi Anabilim Dalı, Kayseri.

Vural, M., Karavelioğulları, F. A., \& Polat, H. (1997). Çiçekdağı (Kırşehir) ve Çevresinin Etnobotanik Özellikleri, OT Sistematik Botanik Dergisi, 4 (1),117-124.

Yapıcı, İ.Ü., Hoşgören, H., \& Saya Ö. (2009). Kurtalan (Siirt) ilçesinin etnobotanik özellikleri. Dicle Üniversitesi Ziya Gökalp Eğitim Fakültesi Dergisi, 12, 191- 196.

Yeşil, Y. (2007). Kürecik (Akçadağ/Malatya) Bucağında Etnobotanik Bir Araştırma. (Yayınlanmamış Yükssek Lisans Tezi) İstanbul Üniversitesi Sağllk Bilimleri Enstitüsü, İstanbul.

Yıldırımlı, Ş. (1991). Munzur dağlarının tıbbi ve endüstriyel bitkileri. Fırat Havzası Tıbbi ve Endüstriyel Bitkileri Sempozyumu.(S., 83-102). Ankara. 